\title{
PRAKTYKA OPODATKOWANIA WYROBISK GÓRNICZYCH PO WYROKU TRYBUNAŁU KONSTYTUCYJNEGO Z DNIA 13 WRZEŚNIA 2011 ROKU (P 33/09)
}

\section{WPROWADZENIE}

Od dłuższego czasu kwestią rodzącą liczne rozbieżności w orzecznictwie organów podatkowych i sądów administracyjnych jest zagadnienie opodatkowania podatkiem od nieruchomości podziemnych wyrobisk górniczych i znajdujących się w nich urządzeń1. Wątpliwości pojawiły się już na tle stanu prawnego obowiązującego przed dniem 1 stycznia 2003 r. i jak się wydaje nadal są aktualne. Wynikały z niejasności w brzmieniu definicji legalnych dotyczących wspomnianej problematyki. Dotyczyło to wykładni przepisów ustawy z dnia 12 stycznia $1991 \mathrm{r}$. o podatkach i opłatach lokalnych (która we wskazanym okresie nie zawierała legalnej definicji budowli) ${ }^{2}$, ustawy z dnia 7 lipca 1994 r. - Prawo budowlane ${ }^{3}$

Dr hab. Pawee Smoleń, prof. KUL - kierownik Katedry Finansów i Prawa Finansowego, Instytut Nauk Prawnych, Wydział Prawa, Prawa Kanonicznego i Administracji, Katolicki Uniwersytet Lubelski Jana Pawła II, Al. Racławickie 14, 20-950 Lublin; e-mail: pasmo@kul.pl; https://orcid. org/0000-0001-6607-3446

Dr Marzena ŚwistaK - adiunkt w Katedrze Prawa Informatycznego i Zawodów Prawniczych, Wydział Prawa i Administracji, Uniwersytet Marii Curie-Skłodowskiej w Lublinie, Plac Marii Skłodowskiej-Curie 5, 20-031 Lublin; e-mail: marzena.swistak@poczta.umcs.lublin.pl; https://orcid. org/0000-0002-3910-6019

${ }^{1}$ Tak też: B. BrzezIŃsKi, W. MorawsKi, Glosa do wyroku Trybunału Konstytucyjnego z dnia 13 września 2011 r. (P 33/09) - opodatkowanie podatkiem od nieruchomości podziemnych wyrobisk górniczych, „Przegląd Orzecznictwa Podatkowego” 1 (2012), s. 22 i cyt. tam literatura; B. BrzezIŃski, A. Nita, Glosa do wyroku Trybunału Konstytucyjnego z dnia 13 września 2011 r., P 33/09 - pojęcie budowli w podatku od nieruchomości, „Przegląd Orzecznictwa Podatkowego” 1 (2013), s. 7.

${ }^{2}$ Art. 1a dodany art. 1 pkt 2 ustawy z dnia 30 października 2002 r. o zmianie ustawy o podatkach i opłatach lokalnych oraz zmianie niektórych innych ustaw, Dz. U. Nr 200, poz. 1683 [dalej cyt.: ustawa zmieniająca].

${ }^{3}$ Art. 3 pkt 3 w zw. z art. 2 ust. 1 Prawa budowlanego. 
oraz ustawy z dnia 4 lutego 1994 r. - Prawo geologiczne i górnicze ${ }^{4}$ (niestety odnosi się to także do obowiązującej ustawy z dnia 9 czerwca 2011 r. - Prawo geologiczne i górnicze) $)^{5}$.

W starszym orzecznictwie sądowym można było wyodrębnić dwie grupy stanowisk. Po pierwsze przyjmowano, że pojęcie budowli powinno być rozumiane zgodnie ze znaczeniem nadanym mu w języku potocznym ${ }^{6}$, czyli jako obiekt wybudowany przez człowieka ${ }^{7}$, który jest trwale związany z gruntem. Tak rozumiane wyrobisko górnicze mieściłoby się $\mathrm{w}$ tej definicji budowli ${ }^{8}$. Zwolennicy drugiego poglądu wskazywali, że pojęcie budowli dla celów ustawy o podatkach i opłatach lokalnych powinno być rozumiane zgodnie ze znaczeniem tego pojęcia nadanym mu przez przepisy prawa budowlanego. W związku z tym, że przepisy prawa budowlanego stanowią, iż ustawy tej nie stosuje się do podziemnych wyrobisk górniczych ${ }^{9}$, to wyrobisko górnicze nie stanowiłoby budowli podlegającej opodatkowaniu. Co więcej, ówczesne Prawo geologiczne i górnicze zawierało samodzielną regulację, w myśl której obiektami budowlanymi zakładu górniczego były wyłącznie obiekty usytuowane na powierzchni ziemi ${ }^{10}$, co mogło także potwierdzać, że podziemne wyrobiska górnicze nie podlegają opodatkowaniu podatkiem od nieruchomości ${ }^{11}$.

Wobec narastających wątpliwości Rzecznik Praw Obywatelskich wystąpił do Sądu Najwyższego o podjęcie uchwały mającej na celu wyjaśnienie, czy na podstawie przepisów ustawy o podatkach i opłatach lokalnych podziemne wyrobisko

${ }^{4}$ Art. 57-58 ustawy z dnia 4 lutego 1994 r. - Prawo geologiczne i górnicze, Dz. U. z 2005 r. Nr 228, poz. 1947 z późn. zm. [dalej cyt.: dawne Prawo geologiczne i górnicze].

${ }^{5}$ Dz. U. z 2019 r., poz. 868 z późn. zm. [dalej cyt.: nowe Prawo geologiczne i górnicze].

${ }^{6}$ M.in. NSA w uchwale z dnia 29 listopada 1999 r., sygn. akt I FPK 3/99, ONSA 2000, nr 2, poz. 59; pogląd NSA został zakwestionowany przez uchwałę 7 sędziów NSA z dnia 2 lipca $2001 \mathrm{r}$., sygn. akt FPS 2/01, LEX nr 48076. Tak: W. KROK, Budowla w podatku od nieruchomości, Warszawa 2010, LEX/el.

${ }^{7}$ Stownik Języka Polskiego, red. W. Doroszewski, [w:] https://sjp.pwn.pl/doroszewski/budowla;5415191.html [dostęp: 4.09.2019].

${ }^{8}$ Tak: KRoK, Budowla w podatku od nieruchomości.

${ }^{9}$ Art. 2 ust. 1 Prawa budowlanego.

${ }^{10}$ Art. 58 dawnego Prawa geologicznego i górniczego.

${ }^{11}$ Tak: wyrok NSA z dnia 6 listopada 1996 r., sygn. akt SA/Ka 1913/95, ONSA 1997, nr 4, poz. 159; uchwała NSA z dnia 29 listopada 1999 r., sygn. akt FPK 3/99, ONSA 2000, nr 2, poz. 59 (odmiennie: NSA w uchwale z dnia 29 listopada 1999 r., sygn. akt FPK 3/99, ONSA 2000, nr 2, poz. 59). Odmienne poglądy w zakresie opodatkowania podziemnych wyrobisk górniczych prezentowali także przedstawiciele doktryny, np. B. BrzezińsKi, M. KALINowsKi, Glosa do wyroku NSA z dnia 6 listopada 1996 r., SA/Ka 1913/95, „Przegląd Orzecznictwa Podatkowego” 1 (1999), s. 9698; A. Hanusz, Obowiazek podatkowy w podatku od nieruchomości a wyrobisko górnicze, „Glosa” 2 (2001), s. 20-29; R. MASTALSKI, Opodatkowanie budowli w wyrobiskach górniczych, „Przegląd Podatkowy" 12 (2001), 37-39. 
górnicze podlega opodatkowaniu podatkiem od nieruchomości. Sąd Najwyższy w uchwale 7 sędziów ${ }^{12}$ potwierdził, że uznanie podziemnego wyrobiska górniczego za budowlę (będącą obiektem budowlanym) w rozumieniu Prawa budowlanego i ustawy o podatkach i opłatach lokalnych, jest bezpodstawne. Taka interpretacja nie znajduje bowiem potwierdzenia w przepisach Prawa górniczego i geologicznego ${ }^{13}$, które wykluczają kwalifikowanie nie tylko podziemnego wyrobiska górniczego jako całości, lecz także obiektów i urządzeń w nim umieszczonych, jako budowli w rozumieniu ustawy o podatkach i opłatach lokalnych. Podobnie stwierdzil w uchwale 7 sędziów NSA wskazując, że „na gruncie języka prawniczego, w świetle przepisów Prawa budowlanego budowlą jest każdy obiekt budowlany niebędący budynkiem lub obiektem małej architektury ${ }^{14}$. Definicja ta jednak, podobnie jak przykładowe wyliczenie budowli, nie daje odpowiedzi na pytanie, czy budowlą jest także podziemne wyrobisko górnicze. Wiadomo jedynie, że takie wyrobisko nie jest ani budynkiem ${ }^{15}$, ani obiektem małej architektury ${ }^{16} \mathrm{w}$ rozumieniu przepisów Prawa budowlanego. Skoro jednak przepisów tej ustawy nie stosuje się do wyrobisk górniczych ${ }^{17}$, a jednocześnie jej przepisy nie naruszają prawa geologicznego i górniczego w odniesieniu do obiektów budowlanych zakładów górniczych, to - po pierwsze - prawo budowlane stosuje się do obiektów budowlanych zakładów górniczych (choć nie narusza ono przepisów szczególnych), a - po drugie - wyrobiska górnicze nie są obiektami budowlanymi zakładów górniczych. W przeciwnym razie zbędne byłoby wprowadzanie ustępu 1 do art. 2 Prawa budowlanego, jak również użycie różnych czasowników („nie stosuje się” i „nie naruszają”,",18. Tym samym potwierdzono, że zaliczenie podziemnych wyrobisk górniczych w klasyfikacji rodzajowej środków trwałych do kategorii budowli nie daje podstawy do objęcia ich obowiązkiem podatkowym w podatku od nieruchomości.

Rozbieżności uwidaczniające się w orzecznictwie, które odnosiły się do przepisów ustawy o podatkach i opłatach lokalnych w brzmieniu obowiązującym przed dniem 1 stycznia 2003 r., pozostały aktualne w stanie prawnym obowiązującym po 2003 r. Stało się tak, pomimo tego, że obowiązująca od dnia 1 stycznia 2003 r. nowelizacja ustawy o podatkach i opłatach lokalnych ${ }^{19}$, wprowadzając do

\footnotetext{
${ }^{12}$ Uchwała SN z dnia 12 marca 2002 r., sygn. akt III ZP 34/01, OSNP 2002, nr 23, poz. 561.

${ }^{13} \mathrm{~W}$ szczególności w brzmieniu art. 58 dawnego Prawa geologicznego i górniczego.

${ }^{14}$ Art. 3 pkt 3 Prawa budowlanego.

${ }^{15}$ Art. 3 pkt 2 Prawa budowlanego.

${ }^{16}$ Art. 3 pkt 4 Prawa budowlanego.

${ }^{17}$ Art. 2 ust. 1 Prawa budowlanego.

${ }^{18}$ Uchwała 7 sędziów NSA z dnia 2 lipca 2001 r., sygn. akt FPS 2/01, LEX nr 48076.

${ }^{19}$ Ustawa z dnia 30 października 2002 r. o zmianie ustawy o podatkach i opłatach lokalnych oraz o zmianie niektórych innych ustaw, Dz. U. Nr 200, poz. 1683.
} 
ustawy legalną definicję budowli, miała doprecyzować przedmiot opodatkowania podatkiem od nieruchomości i potwierdzić funkcjonującą w praktyce orzeczniczej definicję tego pojęcia. W konsekwencji miało to wyeliminować zaistniałe trudności interpretacyjne ${ }^{20}$.

Należy jednak zauważyć, że zarówno na gruncie stanu prawnego obowiązującego do dnia 1 stycznia 2003 r., jak i w okresie późniejszym, zakres pojęciowy definicji „budowli” na podstawie przepisów Prawa budowlanego - jako przedmiotu opodatkowania podatkiem od nieruchomości - pozostał tożsamy. W świetle przepisów cytowanej ustawy ${ }^{21}$, budowlą jest każdy obiekt budowlany niebędący budynkiem lub obiektem małej architektury. Wciąż definicja ta, podobnie jak przykładowe w tym przepisie wyliczenie obiektów mogących stanowić budowle, nie dawała odpowiedzi na pytanie, czy budowlą jest także podziemne wyrobisko górnicze. Wiadomo było jedynie, że takie wyrobisko nie jest budynkiem lub obiektem małej architektury w rozumieniu przepisów Prawa budowlanego ${ }^{22}$, a sięgając do brzmienia przepisów Prawa budowlanego i dawnego Prawa geologicznego i górniczego, należało wskazać, że wyrobiska górnicze nie są także obiektami budowlanymi zakładów górniczych. Skoro podziemne wyrobisko górnicze nie jest obiektem budowlanym, a każda budowla stanowi obiekt budowlany, to w orzecznictwie wyprowadzono wniosek, że podziemne wyrobisko górnicze nie jest budowlą ${ }^{23}$

Należy zauważyć, że linia orzecznicza po nowelizacji ustawy o podatkach i opłatach lokalnych, która weszła w życie z dniem 1 stycznia 2003 r., nie była stabilna. Pojawiały się bowiem wyroki skrajnie odmienne. Nadto, wielokrotnie sądy administracyjne powracały do stanowiska, zgodnie z którym podziemne wyrobisko górnicze miało podlegać opodatkowaniu. Prezentowano argumentację, iż według przepisów ustawy o podatkach i opłatach lokalnych opodatkowaniu podatkiem od nieruchomości podlegają obiekty budowlane w rozumieniu Prawa budowlanego. Jakkolwiek Prawo budowlane wyłącza stosowanie tej ustawy do wyrobisk górniczych, to wyrobiska górnicze stanowią obiekty budowlane w rozumieniu Prawa budowlanego, do których nie stosuje się jedynie przepisów tej ustawy. Sądy przyjmowały także stanowisko organów podatkowych, zgodnie z którym opodatkowaniu podlegają również wszelkiego rodzaju urządzenia techniczne, zlokalizowane w podziemnym wyrobisku górniczym. Urządzenia te miałyby bowiem stanowić

\footnotetext{
20 Tak też: NSA w wyroku z dnia 27 stycznia 2006 r., sygn. akt FSK 2316/04, LEX nr 181362.

${ }^{21}$ Art. 3 pkt 3 Prawa budowlanego.

${ }^{22}$ Art. 3 pkt 3-4 Prawa budowlanego.

${ }^{23}$ Podobny pogląd został zaprezentowany w wyroku NSA z dnia 21 marca 2003 r., sygn. akt I SA/Po 315/02, LEX nr 144616, w którym sąd wskazał, że: „Jeżeli prawo geologiczne i górnicze odróżnia podziemne wyrobisko górnicze i budowlane, to wykluczone jest uznanie podziemnego wyrobiska górniczego za przedmiot opodatkowania podatkiem od nieruchomości”.
} 
całość techniczno-użytkową z wyrobiskiem ${ }^{24}$. Jednocześnie przy tym pojawiały się również odmienne poglądy, że obiekty niebędące obiektami budowlanymi zakładu górniczego w rozumieniu ustawy - Prawo geologiczne i górnicze nie stanowią budowli i nie podlegają opodatkowaniu ${ }^{25}$.

Duża niejednolitość i labilność orzecznictwa co do opodatkowania wyrobisk górniczych i obiektów, które się w nich znajdują, spowodowała, że Wojewódzki Sąd Administracyjny w Gliwicach wystąpił do TK z wnioskiem o zbadanie konstytucyjności przepisów ustawy o podatkach i opłatach lokalnych w zakresie, w jakim definiują budowlę jako przedmiot opodatkowania ${ }^{26}$.

\section{WYROBISKO GÓRNICZE}

\section{W ŚWIETLE WYROKU TRYBUNAEU KONSTYTUCYJNEGO - ANALIZA WĘZŁOWYCH ZAGADNIEŃ}

Jak wiadomo $\mathrm{TK}^{27}$ stwierdził, że wskazane przez WSA w Gliwicach problemy dotyczące kwalifikacji obiektów i urządzeń znajdujących się w podziemnych wyrobiskach górniczych oraz samych wyrobisk jako budowli podlegających opodatkowaniu podatkiem od nieruchomości, będące niewątpliwie konsekwencją

\footnotetext{
${ }^{24}$ Tak np. wyrok WSA we Wrocławiu z dnia 11 września 2004 r., sygn. akt I SA/Wr 3364/02, niepubl; wyrok WSA we Wrocławiu z dnia 5 października 2006 r., sygn. akt I SA/Wr 161/05, LEX nr 894208; wyrok WSA we Wrocławiu z dnia 26 września 2007 r., sygn. akt I SA/Wr 964/07, LEX nr 1009632; wyrok WSA we Wrocławiu z dnia 18 grudnia 2007 r., sygn. akt I SA/Wr 1004/07, LEX nr 1007763; wyrok WSA w Lublinie z dnia 22 września 2010 r., sygn. akt I SA/Lu 657/09, LEX nr 749489, wyrok WSA w Gliwicach z dnia 16 lutego 2009 r., sygn. akt I SA/Gl 953/08, LEX nr 512078; wyrok WSA w Gliwicach z dnia 9 lutego 2009 r., sygn. akt I SA/G1 345/08, LEX nr 511372; wyrok NSA z dnia 27 listopada 2007 r., sygn. akt II FSK 1329/06, LEX nr 926689; wyrok NSA z dnia 13 sierpnia 2010 r., sygn. akt II FSK 342/09, LEX nr 590685; wyrok NSA z dnia 13 sierpnia 2010 r., sygn. akt II FSK 2069/09, LEX nr 745719.

${ }^{25}$ Tak np. wyrok NSA z dnia 20 września 2007 r., sygn. akt II FSK 1016/06, LEX nr 389400.

${ }^{26}$ Postanowienie WSA w Gliwicach z dnia 1 czerwca 2009 r., sygn. akt I SA/G1 110/09, LEX nr 532941. Sąd przedstawił Trybunałowi Konstytucyjnemu następujące pytanie prawne: czy art. la ust. 1 pkt 2 w związku z art. 2 ust. 1 pkt 3 ustawy o podatkach i opłatach lokalnych jest zgodny z art. $217 \mathrm{w}$ związku z art. 84 i art. 2 Konstytucji. Trybunał Konstytucyjny zauważył, że zgodność powiązanych ze sobą art. la ust. 1 pkt 2 i art. 2 ust. 1 pkt 3 ustawy o podatkach i opłatach lokalnych $\mathrm{z}$ art. 2, art. $84 \mathrm{i}$ art. 217 Konstytucji była wcześniej dwukrotnie kwestionowana w drodze skarg konstytucyjnych, jednak postępowania zainicjowane tymi skargami zostały umorzone ze względu na brak zdolności skargowej podmiotów je wnoszących (zob. postanowienia TK: z 8 kwietnia $2008 \mathrm{r}$., sygn. akt SK 80/06, OTK ZU nr 3/A/2008, poz. 51, oraz z 6 kwietnia 2011 r., sygn. akt SK 21/07, OTK ZU nr 3/A/2011, poz. 28). Powyższe jednak nie tworzyło przeszkody w rozpoznaniu pytania prawnego przedstawionego przez WSA w Gliwicach.

${ }^{27}$ Wyrok TK z dnia 13 września 2011 r., sygn. akt P 33/09, LEX nr 929854 [dalej cyt.: wyrok TK].
} 
istotnych wątpliwości interpretacyjnych, są w świetle standardów konstytucyjnych rzeczywiste, obiektywne i poważne ${ }^{28}$.

Rozstrzygnięcie TK w niniejszej sprawie przybrało postać wyroku interpretacyjnego $^{29}$. Jak podnosi się $\mathrm{w}$ doktrynie, zadaniem takich orzeczeń nie jest usuwanie niejednolitości i rozbieżności wykładni przepisów prawa, lecz eliminacja spośród możliwych wariantów interpretacyjnych kontrolowanego przepisu, który jest niezgodny z Konstytucją ${ }^{30}$. Uzasadnieniem dla wydania tego typu wyroku jest założenie, iż skoro poddany kontroli Trybunału Konstytucyjnego przepis może być interpretowany w sposób zgodny z Konstytucją, to nie ma powodu do wydawania wyroku pozbawiającego ten przepis mocy obowiązującej. Wyroki interpretacyjne

${ }^{28}$ Trybunał Konstytucyjny w swoim wyroku wskazał, że „stwierdzenie niezgodności określonej regulacji z ustawą zasadniczą ze względu na jej niejednoznaczność czy nieprecyzyjność będzie uzasadnione wyłącznie wówczas, gdy wątpliwości interpretacyjne w zakresie danego przepisu mają charakter kwalifikowany. Przesłanka ta zachodzi, jeżeli: 1) rozstrzygnięcie omawianych wątpliwości nie jest możliwe na podstawie reguł egzegezy tekstu prawnego przyjętych w kulturze prawnej, 2) zastosowanie wskazanych reguł nie pozwala na wyeliminowanie rozważanych wątpliwości bez konieczności podejmowania przez organ władzy publicznej decyzji w istocie arbitralnych (w tym wypadku możemy mieć do czynienia nie tylko z naruszeniem zasady poprawnej legislacji, lecz także zasady podziału władzy, wyrażonej w art. 10 Konstytucji, skoro ostatecznie o treści obowiązujących uregulowań nie decydują tu organy upoważnione do tworzenia prawa, ale organy powołane do jego stosowania) bądź 3) trudności w ich usunięciu, szczególnie z punktu widzenia adresatów danej regulacji, okazują się rażąco nadmierne, czego nie można usprawiedliwić złożonością normowanej materii”. Jak przyjął TK ,dla stwierdzenia niezgodności z Konstytucją nie wystarcza jednak tylko i wyłącznie abstrakcyjne stwierdzenie faktu występowania niejasności lub rozbieżności interpretacyjnych. [...] Niejasność przepisu może uzasadniać stwierdzenie jego niezgodności z Konstytucją, o ile jest tak daleko posunięta, iż wynikających z niej rozbieżności nie da się usunąć za pomocą zwyczajnych środków mających na celu wyeliminowanie niejednolitości w stosowaniu prawa. Niejasność przepisu powodująca jego niekonstytucyjność musi mieć charakter „kwalifikowany”, przez wystąpienie określonych dodatkowych okoliczności z nią związanych, które nie mają miejsca w każdym przypadku wątpliwości co do rozumienia określonego przepisu. Dlatego tylko daleko idące, istotne rozbieżności interpretacyjne albo już występujące w praktyce, albo - jak to ma miejsce w przypadku kontroli prewencyjnej - takie, których z bardzo wysokim prawdopodobieństwem można się spodziewać w przyszłości, mogą być podstawą stwierdzenia niezgodności z Konstytucją określonego przepisu prawa. Ponadto skutki tych rozbieżności muszą być istotne dla adresatów i wynikać z niejednolitego stosowania lub niepewności co do sposobu stosowania. Dotykać one winny prawnie chronionych interesów adresatów norm prawnych i występować w pewnym nasileniu". Tak też: Wyrok TK z dnia 3 grudnia 2002 r., sygn. akt P 13/02, LEX nr 57099; podobnie: postanowienie TK z 27 kwietnia 2004 r., sygn. akt P 16/03, LEX nr 107520.

${ }^{29}$ Trybunał uznał, że art. 2 ust. 1 pkt 3 w związku z art. la ust. 1 pkt 2 ustawy o podatkach i opłatach lokalnych, rozumiany w taki sposób, że nie odnosi się do podziemnych wyrobisk górniczych oraz może odnosić się do obiektów i urządzeń zlokalizowanych w tych wyrobiskach, jest zgodny z zasadą ustawowej określoności regulacji podatkowych i zasadą poprawnej legislacji wywodzonymi z art. 217 w związku z art. 84 i art. 2 Konstytucji Rzeczypospolitej Polskiej.

${ }^{30}$ Ustawa z dnia 2 kwietnia 1997 r. - Konstytucja Rzeczypospolitej Polskiej, Dz. U. Nr 78, poz. 483. 
oparte są na metodzie wykładni w zgodzie z Konstytucją, która polega na nadaniu kontrolowanemu przepisowi takiego rozumienia, przy którym jest on zgodny z normami i wartościami konstytucyjnymi. W literaturze zwraca się uwagę, że wykładnia ta nie może jednak prowadzić do podważenia jednoznacznego rezultatu wykładni językowej oraz nie może być zastosowana w sytuacji, w której ustawa nie spełnia wymogu określoności regulacji prawnej dotyczącej podstawowych praw jednostki ${ }^{31}$. W tych wypadkach TK powinien stwierdzić niekonstytucyjność przepisu i zrezygnować $\mathrm{z}$ ustalenia $\mathrm{w}$ sentencji zgodnego $\mathrm{z}$ Konstytucją jego rozumienia $^{32}$. Wyroki takie mają także walor powszechności ${ }^{33}$.

Argumentacja zawarta w uzasadnieniu wyroku jest niezwykle obszerna. Koncentrując się zatem na praktycznym wydźwięku wyroku TK, można ukazać jego treść w sposób dwuwymiarowy. Po pierwsze, zasadnicza teza sprowadza się do stwierdzenia, że podziemne wyrobisko górnicze jako takie nie podlega opodatkowaniu podatkiem od nieruchomości. Stwierdzenie takie porządkuje dotychczasową dyskusję i niejednolite orzecznictwo w tym zakresie. Po drugie, TK podniósł, że wyłączenie wyrobiska górniczego nie wyklucza opodatkowania budowli znajdujących się w podziemnym wyrobisku górniczym (,przepisy podatkowe mogą odnosić się do obiektów i urządzeń zlokalizowanych w tych wyrobiskach").

Odnosząc się do pierwszej warstwy merytorycznego wydźwięku wyroku TK, wypada jedynie podkreślić stwierdzenie TK, iż zakwestionowana regulacja przewidująca opodatkowanie podatkiem od nieruchomości budowli w rozumieniu ustawy o podatkach i opłatach lokalnych nie narusza ustawy zasadniczej, jeżeli będzie interpretowana jako nieodnosząca się do podziemnych wyrobisk górniczych. W ocenie TK oznacza to, iż w świetle obowiązujących przepisów prawa opodatkowanie wskazanych wyrobisk należy uznać za niedopuszczalne z konstytucyjnego punktu widzenia. Zdaniem TK, niezależnie od obiektywnie występujących trudności, możliwe wydaje się wyeliminowanie wątpliwości dotyczących opodatkowania podziemnych wyrobisk górniczych oraz znajdujących się w nich obiektów i urządzeń,

${ }^{31} \mathrm{~W}$ tym zakresie polemizuje z wyrokiem TK P. BANASIK, Załacznik do ustawy - prawo budowlane a jego wplyw na określenie przedmiotu, w podatku od nieruchomości, „Przegląd Podatków Lokalnych i Finansów Samorządowych" 3 (205) 2018, s. 11.

32 Tak: J. TrzciŃski, Orzeczenia interpretacyjne Trybunatu Konstytucyjnego, „Państwo i Prawo” 1 (2002), s. 10; M. Granat, Prawo konstytucyjne w pytaniach i odpowiedziach, Warszawa: Wolters Kluwer 2014, s. 338; M. FlorCZAK-WąTOR, Orzeczenia Trybunatu Konstytucyjnego i ich skutki prawne, Poznań: Ars Boni et Aequi 2006, s. 112-129; T. Woś, Wyroki interpretacyjne i zakresowe w orzecznictwie Trybunatu Konstytucyjnego, „Studia Iuridica Lublinensia” 3 (25) 2016, s. 987-988; R. MAstalski, Glosa do wyroku TK z 13 września 2011 r., P 33/09, „Przegląd Sejmowy” 2 (109) 2012, s. 180.

${ }^{33}$ Tak też: A. Olechno, Wplyw orzecznictwa TK na stosowanie prawa podatkowego $w$ Polsce, „Przegląd Podatków Lokalnych i Finansów Samorządowych” 9 (151) 2013, s. 34. 
co wymaga jednak odpowiedniego wykorzystania reguł wykładni, w szczególności reguł systemowych $\mathrm{w}$ aspekcie pionowym, których przejawem jest tzw. technika wykładni ustaw w zgodzie z Konstytucją, oraz reguł funkcjonalnych. Posłużenie się wskazanymi regułami pozwoli zapewnić zgodność rozstrzygnięcia w sprawie. Podziemne wyrobiska górnicze nie są bowiem obiektami budowlanymi (urządzeniami budowlanymi) w ujęciu Prawa budowlanego, lecz przestrzenią powstałą w wyniku prac górniczych, a w konsekwencji nie mogą być kwalifikowane jako budowle na gruncie przepisów Prawa budowlanego. Tym samym nie stanowią one przedmiotu opodatkowania podatkiem od nieruchomości ani samodzielnie (jako wyrobiska w znaczeniu fizycznym), ani razem ze znajdującą się w nich infrastrukturą (jako wyrobiska w znaczeniu kompleksowym).

$\mathrm{Z}$ perspektywy problemów analizowanych $\mathrm{w}$ niniejszym opracowaniu warto również zaakcentować, iż TK wyróżnił trzy możliwe sposoby pojmowania wyrobisk górniczych:

1) w znaczeniu fizycznym wyrobisko traktowane jest jako przestrzeń w nieruchomości gruntowej lub w górotworze powstała w wyniku robót górniczych (gdyby przedmiotem opodatkowania miało być tak rozumiane wyrobisko górnicze, podstawą obliczenia podatku byłaby wartość samej przestrzeni odpowiadająca w zasadzie wartości robót górniczych prowadzących do jej wytworzenia);

2) w znaczeniu technicznym wyrobisko traktowane jest jako zespół funkcjonalnie powiązanych ze sobą urządzeń służących wydobywaniu kopaliny, zlokalizowany $\mathrm{w}$ przestrzeni $\mathrm{w}$ nieruchomości gruntowej lub w górotworze powstałej w wyniku robót górniczych (gdyby przedmiotem opodatkowania miało być tak rozumiane wyrobisko górnicze, podstawą obliczenia podatku byłaby wartość urządzeń);

3) w znaczeniu kompleksowym (pojęcie, za którym opowiadało się orzecznictwo) wyrobisko traktowane jest jako przestrzeń w nieruchomości gruntowej lub $\mathrm{w}$ górotworze powstała $\mathrm{w}$ wyniku robót górniczych wraz ze zlokalizowanymi w niej urządzeniami służącymi wydobywaniu kopaliny (gdyby przedmiotem opodatkowania miało być tak rozumiane wyrobisko górnicze, podstawą obliczenia podatku byłaby wartość samej przestrzeni odpowiadająca w zasadzie wartości robót górniczych prowadzących do jej wytworzenia, zwiększona o wartość umieszczonych w niej urządzeń).

TK stanowczo podkreślił przy tym, że wyrobiska górnicze pojmowane zgodnie z przepisami prawa geologicznego i górniczego jako przestrzenie w nieruchomościach gruntowych lub w górotworach, nie będąc obiektami budowlanymi, nie mogą podlegać opodatkowaniu podatkiem od nieruchomości ani samodzielnie (jako wyrobiska w rozumieniu fizycznym), ani razem ze zlokalizowanymi w nich urządzeniami (jako wyrobiska w rozumieniu kompleksowym). Przyjęcie przeciwnego poglądu 
byłoby równoznaczne z niedopuszczalną konstytucyjnie rozszerzającą wykładnią regulacji podatkowej. Opodatkowaniu podatkiem od nieruchomości jako obiekty budowlane mogłyby podlegać wyrobiska górnicze w znaczeniu technicznym, czyli zespoły funkcjonalnie powiązanych ze sobą urządzeń służących wydobywaniu kopaliny, zlokalizowane $\mathrm{w}$ przestrzeniach $\mathrm{w}$ nieruchomościach gruntowych lub $\mathrm{w}$ górotworach powstałych $\mathrm{w}$ wyniku robót górniczych, o ile takie zespoły dają się zakwalifikować jako obiekty budowlane w postaci budowli w rozumieniu Prawa budowlanego. Wiąże się to jednak z koniecznością przyporządkowania omawianych zespołów do jednej $\mathrm{z}$ nazw budowli wymienionych expressis verbis w prawie budowlanym. Jednakże TK wskazał, że wyróżnienie technicznego pojęcia wyrobiska górniczego wydaje się w świetle przepisów Prawa geologicznego i górniczego nieuzasadnione i może prowadzić do licznych nieporozumień, a w konsekwencji należy z niego zrezygnować, tym bardziej, iż wystarczające, a przy tym jasne, jest rozróżnienie dwóch zagadnień: opodatkowania wyrobisk górniczych w rozumieniu Prawa geologicznego i górniczego i opodatkowania urządzeń umieszczonych $\mathrm{w}$ tak rozumianych wyrobiskach. Zarówno powyższa klasyfikacja, jak i przytoczona argumentacja jest wprost przyjmowana i powielana zarówno przez organy podatkowe, jak i sądy administracyjne w wydawanych wyrokach. Można nawet odnieść wrażenie, że na stałe wpisało się to w kanon nie tylko orzecznictwa, ale i doktryny ${ }^{34}$.

W drugim wymiarze praktycznym TK orzekł z kolei, że zakwestionowana regulacja przewidująca opodatkowanie podatkiem od nieruchomości budowli w rozumieniu ustawy o podatkach i opłatach lokalnych nie narusza ustawy zasadniczej, jeżeli będzie interpretowana jako mogąca się odnosić do obiektów i urządzeń zlokalizowanych w podziemnych wyrobiskach górniczych. Oznacza to, iż w świetle obowiązujących przepisów prawa opodatkowanie wskazanych obiektów i urządzeń rozważanym

${ }^{34}$ Zob. wyrok WSA we Wrocławiu z 9 listopada 2004 r., sygn. akt I SA/Wr 3364/03, LEX nr 715795; wyrok NSA z 3 lutego 2006 r., sygn. akt II FSK 656/05, Lex nr 193322; wyrok WSA we Wrocławiu z 15 marca 2007 r., sygn. akt I SA/Wr 1811/06, LEX nr 923639; wyrok WSA we Wrocławiu z 15 marca 2007 r., sygn. akt I SA/Wr 1814/06, LEX nr 305425; wyrok WSA we Wrocławiu z 16 maja 2007 r., sygn. akt I SA/Wr 1596/06, LEX nr 295449; wyrok NSA z 20 września 2007 r., sygn. akt II FSK 1016/06, LEX nr 389400; wyrok WSA we Wrocławiu z 26 września 2007 r., sygn. akt I SA/Wr 964/07, LEX nr 1009632; wyrok WSA we Wrocławiu z 18 grudnia 2007 r., sygn. akt I SA/Wr 1004/07, LEX nr 1007763; wyrok WSA we Wrocławiu z 18 grudnia 2007 r., sygn. akt I SA/ Wr 1006/07, LEX nr 1007765; wyrok WSA we Wrocławiu z 6 lutego 2008 r., sygn. akt I SA/Wr 944/07, LEX nr 471151; wyrok WSA we Wrocławiu z 14 kwietnia 2008 r., sygn. akt I SA/Wr 1572/07, Lex nr 380935; wyrok NSA z 11 czerwca 2008 r., sygn. akt II FSK 508/07, LEX nr 470141; wyrok NSA z 29 stycznia 2009 r., sygn. akt II FSK 1407/07, LEX nr 537592; wyrok WSA w Gliwicach z 9 lutego 2009 r., sygn. akt I SA/Gl 345/08, LEX nr 511372; wyrok WSA w Gliwicach z 16 lutego 2009 r., sygn. akt I SA/G1 953/08, LEX nr 512078; wyrok NSA z 15 stycznia 2010 r., sygn. akt II FSK 1114/09, LEX nr 558865; wyrok NSA z 13 sierpnia 2010 r., sygn. akt II FSK 342/09, LEX nr 590685. 
podatkiem nie jest wykluczone z konstytucyjnego punktu widzenia. Brak bowiem przepisu, który generalnie wyłączałby możliwość zakwalifikowania elementów infrastruktury usytuowanej w podziemnych wyrobiskach górniczych jako obiektów budowlanych (urządzeń budowlanych) w ujęciu Prawa budowlanego, a tym samym jako budowli na gruncie ustawy o podatkach i opłatach lokalnych. Posłużenie się przez TK w sentencji wyroku zwrotem ,rozumiany w taki sposób, że [...] może odnosić się do" (zamiast zwrotu „rozumiany w taki sposób, że [...] odnosi się do”) nie jest przypadkowe, gdyż TK w swoim wyroku interpretacyjnym nie przesądza, czy rozważane obiekty i urządzenia dają się zakwalifikować jako budowle w ujęciu ustawy o podatkach i opłatach lokalnych. Rozstrzygnięcie tej kwestii pozostawiono kompetencji organów podatkowych oraz sądów administracyjnych. TK podzielił jednocześnie pogląd, że w każdej sprawie podatkowej dotyczącej infrastruktury znajdującej się w podziemnych wyrobiskach górniczych niezbędne jest dokładne ustalenie w prowadzonym postępowaniu, które z obiektów i urządzeń można zakwalifikować jako budowle w rozumieniu ustawy o podatkach i opłatach lokalnych (nie wykluczając opinii biegłych) ${ }^{35}$. TK podkreślił, że wobec dużego zróżnicowania obiektów i urządzeń usytuowanych w podziemnych wyrobiskach górniczych, do których zaliczyć należy, m.in.: urządzenia służące do dostarczania świeżego powietrza (lutniociągi), rurociągi do doprowadzania i odprowadzania wody, przewody sieci energetycznej do napędu urządzeń do transportu i urabiania, przenośniki taśmowe lub zgrzebłowe służące do transportu, urządzenia do prowadzenia urabiania kopalin użytecznych oraz obudowy wyrobiska (podporowe i zmechanizowane), konieczne jest precyzyjne rozważenie, czy poszczególne z tych obiektów i urządzeń, ich zespoły bądź też cała rozważana infrastruktura dają się przyporządkować nazwom budowli wskazanym w prawie budowlanym. TK zwrócił uwagę na konieczność prowadzenia w tym zakresie wyczerpującego postępowania dowodowego, tak aby w uzasadnieniu wydawanych decyzji szczegółowo wyjaśnić podatnikom, jakie względy przemawiały za wydaniem decyzji o określonej treści. Ma to sprzyjać realizacji zasady zaufania jednostki do państwa i stanowionego przezeń prawa, wywodzonej z zasady demokratycznego państwa prawnego (art. 2 Konstytucji). Jak pokazuje jednak praktyka orzecznicza, problem ten niewyjaśniony ostatecznie przez $\mathrm{TK}$, stał się obszarem licznych sporów podatników z organami podatkowymi ${ }^{36}$. Z punktu widzenia podjętej problematyki warto zaznaczyć, że TK przeprowadził analizę definicji legalnych przepisów mających zastosowanie do podziemnych

\footnotetext{
${ }^{35}$ Por. wyrok NSA z 19 października 2010 r., sygn. akt II FSK 907/09, LEX nr 786261.

${ }^{36}$ Tak słusznie zauważa także: K. RADZIKowsKi, Opodatkowanie podatkiem od nieruchomości podziemnych wyrobisk górniczych po wyroku Trybunatu Konstytucyjnego z 13 września 2011 r., P 33/09, „Finanse Komunalne” 3 (2013), s. 75.
} 
wyrobisk górniczych. W pierwszej kolejności zwrócono uwagę na brzmienie definicji budowli zawartej w przepisach ustawy o podatkach i opłatach lokalnych ${ }^{37}$, która niewątpliwie budziła (i niestety nadal budzi) wątpliwości. WSA w Gliwicach wskazał, że nie jest jasne do jakiego aktu prawnego odsyła ustawa o podatkach i opłatach lokalnych - czy jest to wyłącznie prawo budowlane, czy też prawo budowlane jako gałąź prawa ${ }^{38}$. TK potwierdził, że odesłanie dotyczy ustawy - Prawo budowlane. Podniósł dodatkowo, że wątpliwość powstała na skutek niekonsekwencji w stosowaniu sformułowania „przepisy Prawa budowlanego” - zamiast mniej jednoznacznego pojęcia „przepisów prawa budowlanego”. Dodał, że znaczenie określeń „obiekt budowlany” i „urządzenie budowlane” występujących w ustawie o podatkach i opłatach lokalnych zostało objaśnione jedynie w przepisach Prawa budowlanego ${ }^{39}$, nie w przepisach dawnego Prawa geologicznego i górniczego ${ }^{40}$ definiującego jedynie pojęcie „obiektu budowlanego zakładu górniczego” (odmienne od pojęcia „obiektu budowlanego"). Wniosek powyższy pozostał także aktualny po wprowadzeniu nowej ustawy - Prawo geologiczne i górnicze ${ }^{41}$.

TK badając związki normatywne zachodzące pomiędzy definicjami zawartymi w przepisach Prawa budowlanego (,obiekt budowlany”42, „budynek”43, „budowla”44, „obiekt małej architektury” ${ }^{\text {, }}$, „urządzenia budowlane”46) dostrzegł w konstrukcji ustawowych definicji błąd logiczny - tzw. błędne koło pośrednie, które polega na tym, że z jednej strony przez „obiekt budowlany” należy rozumieć „budynek”, „budowlę” i „obiekt małej architektury”, z drugiej zaś „budynek” i „budowla” charakteryzowane są wprost, a „obiekt małej architektury” w domyśle - jako obiekty budowlane ${ }^{47}$.

${ }^{37}$ Art. 1a ust. 1 pkt 2 w zw. z art. 2 ust. 1 pkt 3 w zw. z art. 1 pkt 1 ustawy o podatkach i opłatach lokalnych.

${ }^{38}$ Zob. wyrok NSA z 27 maja 2010 r., sygn. akt II FSK 2049/09, LEX nr 590575; wyrok WSA w Lublinie z 2 lipca 2010 r., sygn. akt I SA/Lu 502/09, LEX nr 603339; wyrok NSA z 13 kwietnia 2011 r., sygn. akt II FSK 144/10, LEX nr 787326; wyrok NSA z 13 kwietnia 2011 r., sygn. akt II FSK 1310/10, LEX nr 1081250.

${ }^{39}$ Art. 3 pkt 1 i 9 Prawa budowlanego.

${ }^{40}$ Art. 58 dawnego Prawa geologicznego i górniczego.

${ }^{41}$ Art. 6 ust. 1 pkt 4 ustawy z dnia 9 czerwca 2011 r. - Prawo geologiczne i górnicze, Dz. U. z 2019, poz. 868 z późn. zm. [dalej cyt.: obowiązujące Prawo geologiczne i górnicze].

${ }^{42}$ Art. 3 pkt 1 Prawa budowlanego.

${ }^{43}$ Art. 3 pkt 2 Prawa budowlanego.

${ }^{44}$ Art. 3 pkt 3 Prawa budowlanego.

${ }^{45}$ Art. 3 pkt 4 Prawa budowlanego.

${ }^{46}$ Art. 3 pkt 9 Prawa budowlanego.

${ }^{47}$ Zob. też: wyrok NSA z 7 października 2009 r., sygn. akt II FSK 635/08, LEX nr 532352; wyrok NSA z 27 maja 2010 r., sygn. akt II FSK 2049/09, LEX nr 590575; wyrok WSA w Lublinie z 2 lipca 2010 r., sygn. akt I SA/Lu 502/09, LEX nr 603339; podobnie: BrZEZIŃSKI, MorAwsKi, Glosa do wyroku Trybunatu Konstytucyjnego z dnia 13 września 2011 r., s. 24. 
Niezależnie od tego, kluczowe dla materii niniejszego artykułu są spostrzeżenia TK dotyczące definicji „,budowli” zwartej w Prawie budowlanym. Wskazano, że formalnie jest to definicja zakresowa równościowa, zgodnie z którą budowlami są wszelkie obiekty wskazane enumeratywnie w jej treści oraz obiekty do nich podobne, z wyjątkiem obiektów zakwalifikowanych jako budynki i obiekty małej architektury. W rzeczywistości jednak przedstawioną definicję należy uznać za definicję zakresową cząstkową. Posłużenie się definicją tego rodzaju w celu zakwalifikowania jakiegoś obiektu jako budowli - jeżeli przedmiotem rozważanej kwalifikacji nie jest obiekt wprost wymieniony pozytywnie lub negatywnie w jej treści - wymaga odwołania się do reguł wykładni funkcjonalnej, a mianowicie do analogii z ustawy (analogia legis). By ustalić, czy dany obiekt może zostać uznany za budowlę, konieczne jest wykazanie, że posiadane przez niego cechy są (argumentum a simili), bądź też nie są (argumentum a contrario) w istotnym zakresie zbliżone do cech posiadanych przez obiekty pełniące rolę wzorców, a za określoną kwalifikacją przemawia dodatkowo odpowiednia argumentacja aksjologiczna ${ }^{48}$.

Ponadto, istotne są wskazania TK w zakresie definicji ,urządzeń budowlanych”,49, którą uznano za definicję równościową klasyczną, z elementami definicji zakresowej cząstkowej. Ze względu na nieostrość terminów w niej występujących jeżeli przedmiotem rozważanej kwalifikacji nie są urządzenia wprost wymienione w treści wskazanej definicji - prawidłowe jej stosowanie może niekiedy wymagać posłużenia się analogią z ustawy (podobnie jak w przypadku definicji „budowli”) ${ }^{50}$.

Podsumowując ten etap analizy, za TK należy podkreślić, że w rozważanych kontekstach odwołanie do przepisów prawa budowlanego trzeba traktować jako odesłanie do Prawa budowlanego. Zastosowanie znajdują tu definicje pojęć: „obiekt budowlany” i ,urządzenie budowlane”, „budynek”, ,budowla” i „obiekt małej architektury". W konsekwencji oznacza to, że ustawa o podatkach i opłatach lokalnych

${ }^{48}$ Za wyrokiem TK z dnia 13 września 2011 r., P 33/09 por. Z. ZIEMBIŃski, Problemy podstawowe prawoznawstwa, Warszawa: PWN 1980, s. 294-295; S. WronkowsKA, Z. ZIEMBIŃsKI, Zarys teorii prawa, Poznań: Ars Boni et Aequi 2001, s. 168-169; wyrok NSA z 7 października 2009 r., sygn. akt II FSK 635/08, LEX nr 532352; wyrok NSA z 5 stycznia 2010 r., sygn. akt II FSK 1101/08, LEX nr 553973; wyrok NSA z 20 kwietnia 2010 r., sygn. akt II FSK 2112/08, LEX nr 576210; wyrok NSA z 13 maja 2010 r., sygn. akt II FSK 2168/08, LEX nr 596292; wyrok NSA z 13 maja 2010 r., sygn. akt II FSK 1066/09, LEX nr 595691; wyrok NSA z 13 maja 2010 r., sygn. akt II FSK 1931/09, LEX nr 596091; wyrok NSA z 13 maja 2010 r., sygn. akt II FSK 1932/09, LEX nr 596093; wyrok NSA z 27 maja 2010 r., sygn. akt II FSK 2049/09, LEX nr 590575; wyrok WSA w Lublinie z 2 lipca 2010 r., sygn. akt I SA/Lu 502/09, LEX nr 603339; wyrok NSA z 13 kwietnia 2011 r., sygn. akt II FSK 144/10, LEX nr 787326; wyrok NSA z 13 kwietnia 2011 r., sygn. akt II FSK 1310/10, LEX nr 1081250.

${ }^{49}$ Art. 3 pkt 9 Prawa budowlanego.

${ }^{50}$ Por. wyrok NSA z 5 stycznia 2010 r., sygn. akt II FSK 1101/08, LEX nr 553973 oraz wyrok NSA z 20 kwietnia 2010 r., sygn. akt II FSK 2112/08, LEX nr 576210. 
będzie miała te same mankamenty i niejasności, które zostały stwierdzone w Prawie budowlanym. Jednak ze względu na to, iż w prawie podatkowym wymagany jest wyższy standard jednoznaczności i określoności przepisów prawnych niż w prawie administracyjnym, uchybienia te w zakresie, w jakim dotyczą regulacji podatkowej, nabierają poważniejszego charakteru ${ }^{51}$. Gwarancje dostatecznej określoności regulacji prawnych wynikające $\mathrm{z}$ zasady poprawnej legislacji ulegają istotnemu wzmocnieniu ze względu na treść art. 84 i art. 217 Konstytucji. Pierwszy z wymienionych przepisów ustawy zasadniczej formułuje nakaz precyzyjnego ustalenia w ustawie wszystkich istotnych elementów stosunku daninowego, natomiast drugi z tych przepisów wskazuje, w odniesieniu do jakich elementów omawianego stosunku (podmioty, przedmiot, stawki, zasady przyznawania ulg i umorzeń oraz kategorie podmiotów zwolnionych) rozważany obowiązek ma charakter szczególny ${ }^{52}$. W praktyce oznacza to m.in., że przepisy prawa podatkowego nie mogą być interpretowane per analogiam, co w tym przypadku byłoby tym bardziej jaskrawe, że odbywałoby się na niekorzyść podatników ${ }^{53}$. Za wyrokiem TK pogląd ten aprobują przedstawiciele doktryny podkreślając, że obowiązki w ustawie podatkowej powinny być określone precyzyjnie, bez wątpliwości interpretacyjnych ${ }^{54}$. Z punktu widzenia standardów konstytucyjnych wskazano, że nie sposób zaakceptować sytuacji, w której jako przedmiot opodatkowania podatkiem od nieruchomości byłyby traktowane budowle w rozumieniu Prawa budowlanego nienależące do kategorii obiektów, które expressis verbis wymienione są w tym przepisie (lub - co wynika z wcześniejszych ustaleń - w pozostałych przepisach rozważanej ustawy albo w załączniku do niej), lecz będące obiektami jedynie do nich podobnymi ${ }^{55}$.

${ }^{51}$ Tak też: Brzeziński, NitA, Glosa do wyroku Trybunatu Konstytucyjnego z dnia 13 września 2011 r., s. 8.

${ }^{52}$ Por. wyroki TK: z 2 kwietnia 2007 r., sygn. akt SK 19/06, OTK ZU nr 4/A/2007, poz. 37; z 9 października 2007 r., sygn. akt SK 70/06; z 27 listopada 2007 r., sygn. akt SK 39/06, OTK ZU nr 10/A/2007, poz. 127; z 10 września 2010 r., sygn. akt P 44/09, OTK ZU nr 7/A/2010, poz. 68.

${ }^{53} \mathrm{Na}$ zakaz ten wskazuje także Ł. KARCZYŃSKI, Glosa do wyroku NSA z dnia 10 marca $2010 \mathrm{r}$, II FSK 1765/08 - istnienie budynku lub budowli w rozumieniu art. 6 ust. 2 ustawy o podatkach i opłatach lokalnych, „Przegląd Orzecznictwa Podatkowego” 5 (2011), s. 434.

${ }^{54}$ Tak m. in. BrZezińsKi, Morawski, Glosa do wyroku Trybunału Konstytucyjnego z dnia 13 września 2011 r., s. 24; G. Jukiel, G. J. WąSIEwski, J. SAPIEŻko-Samordak, Opodatkowanie wyrobisk górniczych. Uwagi na tle pytania prawnego skierowanego do Trybunatu Konstytucyjnego, „Monitor Podatkowy” 1 (2010), s. 27; MASTALSKI, Glosa do wyroku TK z 13 września 2011 r., s. 179; tak też: wyrok SN z dnia 22 października 1992 r., sygn. akt III ARN 50/92, LEX nr 23007.

${ }^{55}$ TK wskazał, że jakkolwiek mogłoby się wydawać, że sformułowana teza nie daje się pogodzić z orzecznictwem sądowym, dopuszczającym opodatkowanie obiektów o cechach zbliżonych do obiektów wprost wskazanych w analizowanej definicji. Jednakże rozbieżność ta występuje wyłącznie na poziomie teoretycznym. 
W dotychczasowej praktyce orzeczniczej sądy administracyjne za przedmiot opodatkowania podatkiem od nieruchomości uznawały budowle wyraźnie określone w art. 3 pkt 3) Prawa budowlanego, natomiast w odniesieniu do innych obiektów, które mogłyby zostać zakwalifikowane jako budowle ze względu na ich istotne podobieństwo do obiektów należących do pierwszej ze wskazanych kategorii, najczęściej nie dopatrywały się istnienia takiego podobieństwa, zastrzegając przy tym, że regulacji prawa podatkowego nie wolno stosować „rozszerzająco" ${ }^{56}$. Oznacza to, że nie każdy obiekt budowlany w postaci budowli w rozumieniu Prawa budowlanego może zostać uznany za budowlę w ujęciu ustawy o podatkach i opłatach lokalnych, a w konsekwencji nie każdy obiekt budowlany w postaci budowli w rozumieniu Prawa budowlanego może podlegać opodatkowaniu podatkiem od nieruchomości. Podobnie nie wszystkie obiekty uznane za urządzenia budowlane w rozumieniu Prawa budowlanego mogą zostać uznane za budowle w ujęciu ustawy o podatkach i opłatach lokalnych, a tym samym podlegać opodatkowaniu podatkiem od nieruchomości. Ze względu na nieostrość terminów występujących w definicji zakwalifikowanie urządzeń jako urządzeń budowlanych może niekiedy wymagałaby posłużenia się analogią z ustawy (co, jak już wspomniano, na gruncie interpretacji przepisów prawa podatkowego byłoby zabiegiem wysoce wątpliwym $)^{57}$, a zakwalifikowanie danego urządzenia często jest zabiegiem bardzo trudnym wymagającym specjalistycznej wiedzy ${ }^{58}$. W konsekwencji, opodatkowaniu na podstawie ustawy o podatkach i opłatach lokalnych podlegać będą tylko te urządzenia budowlane w rozumieniu prawa budowlanego, które bezspornie odpowiadają charakterystyce zawartej w omawianej definicji, a ewentualne wątpliwości należy rozstrzygać w oparciu o argumentum a contrario ${ }^{59}$. Należy przy tym pamiętać, że pojęcie budowli występujące w ustawie o podatkach i opłatach lokalnych nie obejmuje urządzeń budowlanych związanych z obiektami małej architektury.

Ponadto, TK podkreślił, że w prawie podatkowym - inaczej niż w prawie budowlanym jako dziedzinie prawa administracyjnego - obowiązuje restrykcyjnie pojmowana konstytucyjna zasada wyłączności ustawowej, co oznacza, że poza niewielkimi wyjątkami nie dopuszcza się regulowania zagadnień podatkowych

\footnotetext{
${ }^{56}$ Zob. wyrok WSA w Gdańsku z 28 listopada 2007 r., sygn. akt I SA/Gd 598/07, LEX nr 326607; wyrok NSA z 7 października 2009 r., sygn. akt II FSK 635/08, LEX nr 532352; wyrok NSA z 20 kwietnia 2010 r., sygn. akt II FSK 2112/08, LEX nr 576210

${ }^{57}$ Tak też: M. PoPŁAwsKI, Nowa definicja obiektu budowlanego w prawie budowlanym a opodatkowanie budowli podatkiem od nieruchomości, „Przegląd Podatków Lokalnych i Finansów Samorządowych" 7 (185) 2016, s. 7.

58 Tak też: Ł. Rogowski, Opodatkowanie urządzeń budowlanych podatkiem od nieruchomości, „Przegląd Podatków Lokalnych i Finansów Samorządowych” 2 (216) 2019, s. 18.

${ }^{59}$ Tak też: wyrok WSA w Gliwicach z dnia 19 czerwca 2012 r., sygn. akt I SA/Gl 893/11, LEX nr 1219602.
} 
w aktach podustawowych. Jeśli zatem o zakwalifikowaniu określonego obiektu, czy urządzenia jako budowli bądź urządzenia budowlanego w rozumieniu prawa budowlanego miałyby przesądzać przepisy aktu wykonawczego, to nie istnieją podstawy, by taki obiekt czy urządzenie uznać za budowlę na gruncie przepisów ustawy o podatkach i opłatach lokalnych. Odwołanie się w ustawie o podatkach i opłatach lokalnych do przepisów prawa budowlanego należy bowiem interpretować wyłącznie jako odesłanie do regulacji rangi ustawowej ${ }^{60}$.

W opinii TK - w celu zakwalifikowania obiektów i urządzeń usytuowanych w wyrobiskach górniczych, zarówno odkrywkowych, jak i podziemnych, jako obiektów budowlanych, nie można posługiwać się przepisami rozporządzenia Rady Ministrów z dnia 30 grudnia 1999 r. w sprawie Polskiej Klasyfikacji Obiektów Budowlanych $(\mathrm{PKOB})^{61}$, czy przepisami rozporządzenia Rady Ministrów z dnia 3 października 2016 r. w sprawie Klasyfikacji Środków Trwałych (KŚT) ${ }^{62}$ wydanymi na podstawie przepisów ustawy z dnia 29 czerwca 1995 r. o statystyce publicznej ${ }^{63}$. Przepisy ustawy o statystyce publicznej przewidują, że Rada Ministrów wprowadza standardowe klasyfikacje i nomenklatury podstawowe do określenia przebiegu i opisu procesów gospodarczych i społecznych, jednak te klasyfikacje i nomenklatury, w tym również PKOB i KŚT, stosuje się w statystyce, ewidencji i dokumentacji oraz rachunkowości, a także w urzędowych rejestrach i systemach informacyjnych administracji publicznej. Oznacza to, iż nie mogą one przesądzać o uznaniu danego obiektu za obiekt budowlany czy urządzenie budowlane w rozumieniu Prawa budowlanego, a tym samym decydować o jego opodatkowaniu podatkiem od nieruchomości ${ }^{64}$. Za nieuwzględnieniem wskaza-

${ }^{60}$ Zob. wyrok NSA z 27 maja 2010 r., sygn. akt II FSK 2049/09, LEX nr 590575; wyrok WSA w Lublinie z 2 lipca 2010 r., sygn. akt I SA/Lu 502/09, LEX nr 603339; wyrok NSA z 13 kwietnia 2011 r., sygn. akt II FSK 144/10, LEX nr 787326; wyrok NSA z 13 kwietnia 2011 r., sygn. akt II FSK 1310/10, LEX nr 1081250; odmiennie jednak: wyrok NSA z 30 czerwca 2009 r., sygn. akt II FSK 1411/07, LEX nr 513323, w którym powołano się na pogląd wyrażony w uchwale NSA z 27 kwietnia 2009 r., sygn. akt II FPS 1/09, LEX nr 489351, z zastrzeżeniem, że analiza treści wskazanej uchwały nie potwierdza, by wyrażono w niej zapatrywanie, jakoby odwołanie się do przepisów prawa budowlanego obejmowało również akty wykonawcze wydane na podstawie ustawy - Prawo budowlane.

${ }^{61}$ Dz. U. z 1999 r. Nr 112, poz. 1316 z późn. zm. [dalej cyt.: PKOB].

${ }^{62}$ Dz. U. z 2016 r., poz. 1864 z późn. zm. [dalej cyt.: KŚT].

${ }^{63}$ Dz. U. z 2019 r., poz. 649; tak też: B. PAHL, Glosa do wyroku NSA z dnia 13 września 2012 r., II FSK 1048/12, LEX/el. 2013; tak też: W. Morawski, P. BANASIK, Wyrok TK z dnia 13 września 2011 r., P 33/09 a orzecznictwo sąów administracyjnych, „Monitor Podatkowy” 1 (2014), s. 12.

${ }^{64}$ Zob. uchwała NSA z 18 grudnia 1997 r., sygn. akt FPK 24/97, ONSA nr 2/1998, poz. 46; wyrok NSA z 20 maja 2010 r., sygn. akt II FSK 63/09, LEX nr 596546, i wyrok WSA we Wrocławiu z 5 stycznia 2011 r., sygn. akt III Sa/Wr 579/10, Baza Orzeczeń Sądów Administracyjnych, w których w całości wykluczono możliwość posługiwania się w sprawach dotyczących podatku od nieruchomości rozważanymi klasyfikacjami i nomenklaturami, oraz uchwała NSA z 27 kwietnia 2009 r., sygn. akt II FPS 1/09, LEX nr 489351, i wydany w jej następstwie wyrok NSA z 30 czerwca 2009 r., sygn. akt 
nych aktów wykonawczych przy rozstrzyganiu o statusie obiektów i urządzeń w kontekście opodatkowania ich podatkiem od nieruchomości przemawia poza tym okoliczność, że w prawie podatkowym obowiązuje zasada wyłączności ustawowej, a w konsekwencji rozporządzenie nie może, poza niewielkimi wyjątkami, regulować zagadnień podatkowych ${ }^{65}$.

TK przedstawił także argumentację dotyczącą zasad opodatkowania podatkiem od nieruchomości, odnosząc się do regulacji prawa geologicznego i górniczego. Poczynione uwagi zachowują swoją aktualność także w stosunku do przepisów obowiązującej ustawy, która stanowi, że wyrobiskiem górniczym jest przestrzeń w nieruchomości gruntowej lub w górotworze powstała w wyniku robót górniczych $^{66}$. Tak rozumiane wyrobisko nie może być obiektem budowlanym. TK na marginesie słusznie również zauważył, że definicja wyrażenia „wyrobisko górnicze” oraz definicja wyrażenia „roboty górnicze" ${ }^{97}$, obarczone są błędem logicznym, określanym jako błędne koło pośrednie. Wyrobiskiem górniczym, jak już stwierdzono, jest bowiem przestrzeń w nieruchomości gruntowej lub w górotworze powstała $\mathrm{w}$ wyniku robót górniczych, natomiast robotami górniczymi mają być wykonywanie, utrzymywanie, zabezpieczanie lub likwidowanie wyrobisk górniczych oraz zwałowanie nadkładu w odkrywkowych zakładach górniczych w związku z działalnością regulowaną ustawą. Przeciwko zakwalifikowaniu wyrobisk górniczych jako obiektów budowlanych przemawia także brzmienie definicji ,zakładu górniczego" "68. Ustawodawca odrębnie wskazał w wyliczeniu części składowych zakładu górniczego wyrobiska górnicze i obiekty budowlane (w rozumieniu Prawa budowlanego). W związku z tym nie można przyjąć, by wyrobiska mogły zostać zakwalifikowane jako szczególny rodzaj tych ostatnich ${ }^{69}$. Inaczej, gdyby zamiast

II FSK 1411/07, LEX nr 513323, w których jedynie wyjątkowo dopuszczono, na potrzeby opodatkowania podatkiem od nieruchomości, ostrożne stosowanie tych klasyfikacji i nomenklatur wyłącznie w zakresie odnoszącym się do ustalenia rodzaju budynku, a poza tym za całkowicie wystarczające dla rozstrzygnięcia zawisłej sprawy uznano przepisy ustawy o podatkach i opłatach lokalnych.

${ }^{65}$ Zob. wyrok NSA z 27 maja 2010 r., sygn. akt II FSK 2049/09, LEX nr 590575; wyrok WSA w Lublinie z 2 lipca 2010 r., sygn. akt I SA/Lu 502/09, LEX nr 603339; wyrok NSA z 13 kwietnia 2011 r., sygn. akt II FSK 144/10, LEX nr 787326; wyrok NSA z 13 kwietnia 2011 r., sygn. akt II FSK 1310/10, LEX nr 1081250.

${ }^{66}$ Definicja z art. 6 pkt 10 dawnego Prawa geologicznego i górniczego odpowiada brzmieniu aktualnie obowiązującego art. 6 ust. 1 pkt 17 Prawa geologicznego i górniczego.

${ }^{67}$ Art. 6 pkt 11 dawnego Prawa geologicznego i górniczego - odpowiednio art. 6 ust. 1 pkt 12 obowiązującej ustawy.

${ }^{68}$ Art. 6 pkt 7 dawnego Prawa geologicznego i górniczego - odpowiednio art. 6 ust. 1 pkt 18 obowiązującej ustawy.

${ }^{69}$ Zob. uchwała NSA z 2 lipca 2001 r., sygn. akt FPS 2/01, ONSA nr 1/2002, poz. 2; uchwała SN z 12 marca 2002 r., sygn. akt III ZP 34/01, OSNP nr 23/2002, poz. 561; wyrok WSA we Wrocławiu z 16 maja 2007 r., sygn. akt I SA/Wr 1596/06, LEX nr 295449; wyrok WSA we Wrocławiu 
wyliczenia, w którym znalazły się obiekty budowlane, wskazano na obiekty budowlane zakładu górniczego.

Wypada wspomnieć, że TK przedstawiając rozbudowane rozważania dotyczące aparatu pojęciowego przyjętego w ustawie o podatkach i opłatach lokalnych zwrócił uwagę, na konieczność usunięcia przez ustawodawcę licznych wad legislacyjnych. Przede wszystkim chodzi o to, by nadać definicjom zawartym w Prawie budowlanym i odwołującym się do nich definicjom występującym w ustawie o podatkach i opłatach lokalnych poprawny kształt lub przyjąć niezależne w tym zakresie definicje w ustawie o podatkach i opłatach lokalnych (tę drugą koncepcję TK uznał za właściwą). O takich rozwiązaniach słusznie wspominają także przedstawiciele doktryny, przytaczając propozycje legislacyjne, które jednak nie doczekały się realizacji w uchwalonych przepisach ${ }^{70}$. Prawodawca powinien mieć bowiem na uwadze, że odwoływanie się w aktach normatywnych regulujących dziedziny spraw, w odniesieniu do których obowiązuje wyższy standard jednoznaczności i określoności przepisów prawnych, do treści aktów normatywnych normujących zagadnienia, w wypadku których wskazany standard jest niższy, może prowadzić do naruszenia wymagań wynikających z konstytucyjnej zasady poprawnej legislacji. Powinien zawsze zweryfikować, czy przepisy prawne, do których odsyła, spełniają wymagania legislacyjne właściwe nie tylko dla materii regulowanej przez nie bezpośrednio, lecz także dla materii regulowanej przez nie na skutek odesłania. Zaniechanie wskazanej weryfikacji może bowiem doprowadzić - ze względu na konieczność stosowania częściowo innego zestawu reguł wykładni - do odmiennej interpretacji tych samych przepisów prawnych w zależności od tego, dla potrzeb którego uregulowania są one poddawane analizie ${ }^{71}$.

TK trafnie zaznaczył, że przeprowadzona analiza rozwiązań zawartych w Prawie geologicznym i górniczym ujawniła liczne jej mankamenty legislacyjne, m.in.: pośrednie błędne koło w ramach definicji wyrażeń „wyrobisko górnicze” i „roboty górnicze” oraz brak uregulowania relacji pomiędzy Prawem geologicznym i górniczym i Prawem budowlanym w zakresie odnoszącym się do wyrobisk górniczych, obiektów budowlanych zakładów górniczych i obiektów budowlanych usytuowanych w poszczególnych rodzajach wyrobisk. Wydał zatem zalecenie, by

z 26 września 2007 r., sygn. akt I SA/Wr 964/07, LEX nr 1009632; wyrok WSA w Gliwicach z 9 lutego 2009 r., sygn. akt I SA/Gl 345/08, LEX nr 511372 wraz z glosą K. GiLA, Glosa do wyroku WSA w Gliwicach z dnia 9 lutego 2009 r., I SA/Gl 345/08 - opodatkowanie podatkiem od nieruchomości podziemnych wyrobisk górniczych, „Przegląd Orzecznictwa Podatkowego” 6 (2009), s. 532-536; wyrok WSA w Gliwicach z 16 lutego 2009 r., sygn. akt I SA/Gl 953/08, LEX nr 512078

${ }^{70}$ Tak: R. DowgIER, Projektowane zmiany w ustawie o podatkach $i$ oplatach lokalnych, „Przegląd Podatków Lokalnych i Finansów Samorządowych" 2 (156) 2014, s. 7.

${ }^{71}$ Por. wyrok TK z 27 listopada 2006 r., sygn. K 47/04, OTK ZU nr 10/A/2006, poz. 153. 
ustawodawca ustalił, czy te same wady nie występują w nowo uchwalonej ustawie, a jeśli tak - to powinny niezwłocznie zostać wyeliminowane. Niestety, w nowym Prawie geologicznym i górniczym, nie doszło do usunięcia tych mankamentów legislacyjnych ${ }^{72}$. Wprawdzie ustawodawca podjął próbę zmierzenia się z zadaniem legislacyjnym, jednak nie był w tym zakresie konsekwentny. Świadczy o tym treść uzasadnienia rządowego projektowanej ustawy - Prawo geologiczne i górnicze, złożonej w Sejmie 17 grudnia 2008 r. ${ }^{73}$. Stwierdzono tam, że: „W przepisach art. 6 pkt 2) nowej ustawy - Prawo geologiczne i górnicze została zamieszczona norma, że podziemne wyrobiska górnicze oraz znajdujące się w nich instalacje i urządzenia nie są budowlami ani też urządzeniami budowlanymi w rozumieniu przepisów prawa budowlanego". Wydaje się, że w świetle doświadczeń taki kierunek nowelizacji wydaje się nie tylko racjonalny, ale wręcz pożądany. $Z$ tym większym zadziwieniem należy odnotować, że przytoczony przepis nie został zamieszczony w nowej uchwalonej ustawie - Prawo górnicze i geologiczne.

W naszej ocenie, z punktu widzenia wieloletnich trudności z opodatkowaniem wyrobisk górniczych, byłoby to z pewnością jednoznaczne rozstrzygnięcie praktycznych dylematów. Należy mieć świadomość, że za takim rozwiązaniem nie przemawiają względy natury fiskalnej. Oznaczałoby to bowiem wyłączenie z opodatkowania nie tylko wyrobiska górniczego w sensie fizycznym, ale także wyrobiska o charakterze technicznym i kompleksowym.

Trudno się dziwić, że TK podkreślił, iż wobec konieczności pełnego realizowania zasady demokratycznego państwa prawnego, należy zweryfikować okoliczność, czy uchwalona nowa ustawa - Prawo geologiczne i górnicze, po zmianach wprowadzonych $\mathrm{w}$ toku prac legislacyjnych, w tym usunięciu $\mathrm{z}$ art. 6 pkt 2 dotychczasowej treści, rzeczywiście umożliwia jednoznaczne ustalenie, czy obiekty i urządzenia znajdujące się w podziemnych wyrobiskach górniczych mogą być kwalifikowane jako obiekty budowlane, co pozwoliłoby z kolei udzielić odpowiedzi na pytanie, czy w nowym stanie prawnym rozważane obiekty i urządzenia podlegają opodatkowaniu podatkiem od nieruchomości. W tym kontekście należy podnieść, że skoro projektowany przepis art. 6 pkt 2 rządowego projektu został wykreślony $\mathrm{w}$ toku prac parlamentarnych, rodzi się uzasadnione pytanie o faktyczne intencje ustawodawcy w zakresie opodatkowania wyrobisk górniczych ${ }^{74}$.

\footnotetext{
${ }^{72} \mathrm{Na}$ konieczność podjęcia takich działań wskazuje także R. DowgIER, Budynek czy budowla? Kilka uwag na tle wyroku TK z dnia 13 grudnia 2017 r., SK 48/15, „Przegląd Podatków Lokalnych i Finansów Samorządowych" 4 (206) 2018, s. 34.

${ }^{73}$ Druk sejmowy nr 1696.

${ }^{74}$ Zob. tak też: RADZIKowsKI, Opodatkowanie podatkiem od nieruchomości podziemnych wyrobisk górniczych, s. 75 .
} 


\section{ORZECZNICTWO SĄDOWE PO WYROKU TK}

Omówiony wyrok TK z pewnością ma przełomowe znaczenie dla praktyki opodatkowania wyrobisk górniczych. Przede wszystkim rozstrzygnął zasadniczy dylemat dotyczący wyrobiska górniczego zarówno w znaczeniu fizycznym, jak i kompleksowym, przesądzając, iż jako takie nie stanowi ono przedmiotu opodatkowania. Kwestia ta niejako z istoty rzeczy nie budzi już kontrowersji w orzecznictwie sądowym. Trudno jednak oprzeć się wrażeniu, że o ile to zagadnienie jest obecnie oceniane w sposób jednoznaczny, o tyle opodatkowanie ,wyrobiska w sensie technicznym" nadal - pomimo upływu kilku lat od wyroku TK z $2011 \mathrm{r}$. - sprawia liczne trudności merytoryczne. Wskazuje na to analiza najnowszych orzeczeń sądowych odnoszących się do tego samego podatnika w zakresie sporu trwającego od dłuższego już czasu - w swej genezie sięgającej okresu na długo sprzed daty wydania wspomnianego wyroku TK.

W wyroku z dnia 6 maja 2016 r., I SA/Lu 1344/15 75 WSA w Lublinie oddalił skargę na decyzję Samorządowego Kolegium Odwoławczego w Lublinie w przedmiocie podatku od nieruchomości za budowle położone w wyrobiskach górniczych $^{76}$. Organy podatkowe (obu instancji) uznały, że opodatkowaniu podlegają obudowy podtrzymujące ściany wyrobisk, na których umocowane są m.in. rurociągi przeciwpożarowe i odwadniające, kolejki podwieszane, a także obudowy usytuowane w: szybach, w przestrzeni chodników, komór, pochylni, przekopów oraz torowiska kolei spągowej. Zdaniem organów podatkowych są to budowle mieszczące się w zakresie przedmiotowym opodatkowania przede wszystkim jako tunele w rozumieniu ustawy Prawo budowlane. Oprócz tego rurociągi przeciwpożarowe i odwadniające, kolejki podwieszane, torowiska kolei spągowej tworzą w myśl powołanej ustawy całość techniczno-użytkową i stanowią sieci techniczne. Podkreślić przy tym należy, że podatnik tak w odwołaniu, jak i w skardze do WSA kwestionował przede wszystkim te ustalenia organów podatkowych. WSA nie podzielił jednak argumentacji podatnika uznając, iż co do zasady wymienione powyżej obiekty położone w podziemnych wyrobiskach górniczych (obudowy i mocowane na nich kolejki podwieszane, rurociągi, jak również torowiska kolei spągowej, obudowy szybów, chodników, korytarzy) są budowlami i podlegają opodatkowaniu podatkiem od nieruchomości. Zdaniem sądu, obudowy i mocowane na nich kolejki, rurociągi oraz pozostałe obudowy szybów, chodników, komór, pochylni, przekopów, upadowej, pompowni, rozdzielni, lunety i torowiska kolei spągowej w podziemnych wyrobiskach górniczych tworzą razem techniczno-

\footnotetext{
${ }^{75}$ LEX nr 2075060.

${ }^{76}$ I SA/Lu 1344/15, LEX nr 2075060.
} 
-użytkową całość. Wynika to chociażby z tego, że obudowy są instalowane między innymi po to, aby w dalszej kolejności możliwe było poprowadzenie rurociągów, kolejek podwieszanych czy torowisk kolei spągowej. Stanowią zespół elementów powiązanych ze sobą $\mathrm{w}$ taki sposób, aby zgodnie $\mathrm{z}$ wymogami techniki nadawały się do określonego użytku. Zarówno z technicznego, jak i funkcjonalnego punktu widzenia obiekty te wskutek połączenia spełniają wytyczoną rolę. W ocenie sądu razem stanowią one całość techniczno-użytkową i brak uzasadnienia dla rozdzielenia tej budowli (sieci technicznej) na poszczególne elementy. Konsekwencją takiego stanowiska jest opodatkowanie wszystkich składników tej budowli (całości technicznej i użytkowej) jako sieci technicznej. Łączne określenie ich wartości kształtuje podstawę opodatkowania określoną w ustawie podatkowej. Uzasadniając wyrok WSA przywołał przytoczone wyżej stanowisko TK oraz wywody zawarte w wyrokach NSA ${ }^{77}$. Znamienne przy tym jest to, że podsumowując dokonaną ocenę prawną WSA stwierdził, że zabezpieczająca funkcja spełniana przez obudowy (m.in. przed zawałami ziemi, odłamkami skalnymi, niekontrolowanym wypływem gazów czy wód) sprawia, iż budowle te są konstrukcjami oporowymi, wprost wymienionymi w Prawie budowlanym. Zdaniem sądu ,z punktu widzenia rozpoznania przedmiotu opodatkowania podatkiem od nieruchomości nie ma istotnego znaczenia, że w przypadku kopalni, zakładu górniczego noszą one nazwę obudów".

Analiza przytoczonego wyroku (a zwłaszcza uzasadnienia) prowadzi do wniosku, iż w nawiązaniu do wskazówek zawartych w wyroku interpretacyjnym TK z $2011 \mathrm{r}$. ocena prawna dokonana przez organ podatkowy (w wyniku przeprowadzonego postępowania dowodowego - w tym oględzin i opinii biegłych) pozwala wyróżnić kilka typowych rodzajów budowli wyrobiska górniczego. Mogą to być m.in. tunele, obiekty liniowe, sieci techniczne lub konstrukcje oporowe. Wszystkie te obiekty mieszczą się w definicji budowli zawartej w prawie budowlanym, do którego odsyła ustawa o podatkach i opłatach lokalnych. Symptomatyczne przy tym jest to, że sąd zdaje się twierdzić, iż dla celów opodatkowania istotne jest nie tyle konkretne określenie rodzaju budowli, co uchwycenie typowych cech budowli charakteryzujących obiekty występujące w danym wyrobisku górniczym ${ }^{78}$. Stanowisko takie ma tym bardziej doniosłe skutki praktyczne, że to właśnie faktyczna identyfikacja takich obiektów w trakcie postępowania podatkowego wyznacza główną oś sporu podatnika $\mathrm{z}$ organem podatkowym.

${ }^{77}$ W sprawie o sygn. akt II FSK 1589/10 (por. www.orzeczenia.nsa.gov.pl), w sprawie o sygn. akt II FSK 1096/13 (orzeczenia.nsa.gov.pl - por. sprawa o sygn. akt II FSK 2841/12; sprawa o sygn. akt II FSK 553/12).

${ }^{78}$ Sąd odwołał się do stanowiska zawartego w opracowaniu: J. Drosik, „Przegląd Podatków Lokalnych i Finansów Samorządowych" 3 (2014), s. 12. 
Od rozstrzygnięcia WSA w Lublinie z dnia 6 maja 2016 r. złożono skargę kasacyjną. Zasadnicza warstwa merytoryczna zarzutów podniesionych w skardze kasacyjnej koncentruje się wokół klasyfikacji obiektów i ich definicji, tj. sieć techniczna, obudowa, tunel. NSA w Warszawie w wyroku z dnia 26 lipca 2018 r. oddalił skargę kasacyjną ${ }^{79}$. W uzasadnieniu bezpośrednio odniósł się do przyjętej przez WSA w Lublinie wykładni art. 1a ust. 1 pkt 2 ustawy o podatkach i opłatach lokalnych $\mathrm{w}$ zw. $\mathrm{z}$ art. 3 pkt 3 Prawa budowlanego w kontekście określenia znaczenia budowli oraz zdefiniowania pojęcia „sieć techniczna”. Słusznie zauważył przy tym, że już z językowej struktury przepisu można wywodzić konkretne wnioski. W pierwszej kolejności bowiem następuje odwołanie do obiektu budowlanego, a dopiero następczo do urządzenia budowlanego jako związanego z obiektem budowlanym. Oznacza to, że za budowle w rozumieniu ustawy o podatkach i opłatach lokalnych można uznać jedynie te budowle, które zostały wprost wymienione w art. 3 pkt 3 Prawa budowlanego, w innych przepisach tej ustawy lub w załączniku do niej, a ostatecznie do urządzenia technicznego scharakteryzowanego w art. 3 pkt 9 Prawa budowlanego lub $\mathrm{w}$ innych przepisach tej ustawy albo w załączniku do niej. Nawiązując do wyroku TK z dnia 13 września 2011 r. NSA podzielił pogląd, iż w procesie kwalifikacji składników majątkowych, jako poszczególnych obiektów budowlanych, należy przede wszystkim określić każdy składnik znajdujący się w wyrobisku górniczym i z osobna go ocenić, czy zachodzi tożsamość z nazwą wskazaną w art. 3 pkt 3 Prawa budowlanego. Nie można przy tym kierować się zasadą podobieństwa, istnienia cech zbliżonych. Jeżeli taki zabieg nie przyniesie efektu konieczne staje się ustalenie, czy rozważane obiekty i urządzenia dają się zakwalifikować jako urządzenia budowlane w rozumieniu Prawa budowlanego, które zarazem będą budowlami w rozumieniu ustawy o podatkach i opłatach lokalnych ${ }^{80}$. Bez wątpienia taka ścieżka narracji merytorycznej w trakcie postępowania podatkowego pozwoli organom podatkowym uniknąć wielu trudności z prawidłowym ustaleniem i oznaczeniem potencjalnych przedmiotów opodatkowania w wyrobisku górniczym. Chociaż nie wyklucza to wszystkich wyłaniających się trudności, należy podzielić stanowisko NSA, iż „użyte w art. 3 pkt 3 Prawa budowlanego oznaczenia konkretnych obiektów, które w rozumieniu tego przepisu są budowlami, należy intepretować zgodnie z podstawową regułą wykładni językowej nakazującą przyjęcie takiego ich znaczenia jakie mają one w języku powszechnym (domniemanie języka powszechnego). Odstąpienie od stosowania reguł wykładni językowej musi

${ }^{79}$ Sygn. akt II FSK 2616/16 - skarga została oddalona pomimo - jak podkreślił NSA - częściowo błędnego uzasadnienia wyroku WSA.

${ }^{80}$ Podobna metodologia ustalania, czy dany obiekt jest budowlą, akceptowana jest przez doktrynę (por. L. Etel, Podatek od nieruchomości, Komentarz, LEX/el. 2012). 
być uzasadnione wyraźnymi wskazówkami wynikającymi z treści aktu prawnego lub brakiem możliwości ustalenia zakresu i znaczenia pojęcia użytego w przepisie prawa przy zastosowaniu językowych reguł wykładni”.

Bez wątpienia przyjęcie takich założeń pozwala na skuteczną konfrontację technicznego stanu faktycznego danego wyrobiska górniczego z takimi pojęciami jak: tunel, sieci techniczne, konstrukcje oporowe, czy obudowy. Kwestia ta ma zasadnicze znaczenie nie tylko dla rozstrzygnięcia tej konkretnej sprawy rozpatrywanej w ramach postępowania kasacyjnego. Wydaje się, że ma charakter uniwersalny, szeroko odzwierciedlając - podjęty w wyroku TK - problem opodatkowania wyrobisk górniczych w sensie technicznym. Na ogół przecież obudowy górnicze to obiekty wytworzone metodami budowlanymi z połączonych ze sobą elementów (metalowych lub wykonanych z innych materiałów), które podtrzymują grunt lub górotwór (przez podparcie, rozparcie) w celu utworzenia specyficznego korytarza. Dzięki temu powstaje przestrzeń w górotworze wykorzystywana do przemieszczania ludzi i maszyn, a także do zainstalowania w nich różnorodnych obiektów takich jak rurociągi, kolejki podwieszane i tory kolejki spągowej. $\mathrm{W}$ omawianym wyroku NSA opierając się na takich ustaleniach przyjął (podzielając stanowisko WSA), że wszystkie te cechy pozwalają na stwierdzenie, że tego typu obiekt jest tunelem w rozumieniu art. 3 pkt 3 Prawa budowlanego. Jednoznacznie uznał tezę organów podatkowych o tym, że obudowa wyrobiska jest tunelem, za przekonującą i logiczną. Uzasadniając swoje stanowisko podkreślił, iż „pojęcie tunel swym zakresem obejmuje przede wszystkim tunele służące poprowadzeniu w ich wnętrzu drogi lub torowiska (tunele komunikacyjne). W języku powszechnym tunel oznacza przede wszystkim budowlę służącą poprowadzeniu drogi pod przeszkodą taką jak góra, ciek wodny lub pod powierzchnią ziemi w celu uniknięcie prowadzenia drogi na powierzchni. Budowla ta ma kształt wydhużonej przestrzeni wydrążonej w skale i obudowanej metodami budowlanymi w celu zabezpieczenia jej przed negatywnym oddziaływaniem czynnika zewnętrznego. [...] brak jest przesłanek prawnych do tego ażeby użyte w powołanym przepisie pojęcie tunel ograniczać jedynie do tuneli drogowych, których podstawowym celem jest pełnienie funkcji w zakresie komunikacji odbywającej się na powierzchni ziemi. [...] zatem pojęcie „tunel”, które funkcjonuje $\mathrm{w}$ języku powszechnym obejmuje także obudowy wyrobisk górniczych, gdyż spełniają one cechy tuneli w rozumieniu języka powszechnego". Podzielając taki tok rozumowania NSA (zgodnego przecież w swym wydźwięku z treścią wyroku TK) warto zauważyć, że znacząco poszerza się pole klasyfikacji obiektów położonych w wyrobisku górniczym jako budowli stanowiących przedmiot opodatkowania w podatku od nieruchomości. Specyfika techniczna branży górniczej dodatkowo sprawia, iż pracownicy samorządowych organów podatkowych (nawet przy pomocy biegłych, którzy przecież nie określają przedmiotu opodatkowania) 
stają za każdym razem przed wyjątkowo trudnym wyzwaniem. W naturalny sposób wyłania się tu pytanie o możliwy zakres praktycznej recepcji słusznych skądinąd tez zawartych w wyroku TK.

W omawianym wyroku NSA negatywnie zweryfikował natomiast ustalenia i stanowisko WSA w odniesieniu do tzw. sieci technicznych. NSA uznał, że błędnie zostały zakwalifikowane wszystkie obiekty i urządzenia znajdujące się w podziemnych wyrobiskach górniczych (w tym obudowy podziemnych wyrobisk górniczych, a także obiekty takie jak kolejki podwieszane, kolejki spągowe i rurociągi) - łącznie jako sieci techniczne tworzące całość techniczno-użytkową. NSA zaprezentował zgoła odmienną ocenę, przyjmując, że wspomniane obudowy górnicze posiadają cechy nie „sieci technicznej”, tylko cechy i charakterystykę typową dla tuneli. NSA stanął na stanowisku, że „szereg połączonych ze sobą i umiejscowionych w odrębnym korytarzu kopalni obudów górniczych - stanowi odrębną całość techniczno-użytkową. Elementy obudów połączone ze sobą w obrębie korytarza tworzą jeden obiekt - tunel, stanowiący odrębny obiekt budowlany, niebędący budynkiem oraz obiektem małej architektury, stanowiący całość techniczno-użytkową. Obudowy te, tworząc tunel, stanowią więc budowle, wymienione w art. 3 pkt 3) Prawa budowlanego. Kolejną budowlę w postaci sieci technicznych stanowią rurociągi przeciwpożarowe i odwadniające, umiejscowione w korytarzach kopalni, podobnie jak obiekty kolejki podwieszanej i kolejki spągowej służące do transportu. Stanowią one obiekty budowlane niebędące budynkiem lub obiektem małej architektury, a będące całością techniczno-użytkową. W konsekwencji obiekty te stanowią niezależne od obudów górniczych budowle - sieci techniczne" ${ }^{\text {. }}$. Nie można odmówić słuszności zasadniczemu nurtowi wywodów NSA. W sposób bezpośredni korespondują one przecież z zasadami rzetelnego postępowania podatkowego (postępowania dowodowego). W tym miejscu warto jedynie wyeksponować, że niezależnie od jasno zarysowanej linii podziału oceny prawnej dokonanej przez WSA i NSA, za każdym razem gdy jest mowa o: tunelu, sieci technicznej, czy konstrukcji oporowej to są to obiekty będące w rozumieniu przepisów Prawa budowlanego budowlami, niewątpliwie podlegającymi opodatkowaniu podatkiem od nieruchomości.

W celu ukazania rysujących się kontrowersji praktycznych warto ująć problematykę opodatkowania wyrobisk górniczych w nieco poszerzonej perspektywie. Omówione powyżej trudności z klasyfikacją obiektów położonych w wyrobiskach

\footnotetext{
${ }^{81}$ Naczelny Sąd Administracyjny wydając wyrok w niniejszej sprawie podzielił stanowisko NSA wyrażone w wydanych w stosunku do skarżącej spółki, wyrokach z dnia 8 lutego 2018 r., sygn. akt: II FSK 2869/16, II FSK 2870/16 i II FSK 2871/16, którymi uznano, że obudowy górnicze znajdujące się w wyrobiskach górniczych stanowią tunele w rozumieniu art. 3 pkt 3 P.p. oraz, że znajdujące się w nich rurociągi i tory kolejki stanowią wskazane w tym przepisie sieci techniczne.
} 
górniczych wystąpiły również w kolejnych wyrokach sądowych. Szczególnej pikanterii dodaje okoliczność, iż oba wyroki (WSA i NSA) dotyczą tego samego podatnika. Dodatkowo organy podatkowe stanowczo podkreślały, że dotyczą one „tożsamych lub podobnych obiektów”, wobec których zapadły już wyroki NSA podzielające dokonaną klasyfikację opodatkowanych budowli (tunele, sieci techniczne).

W wyroku z dnia 27 czerwca 2018 r., I SA/Lu 337/18 ${ }^{82}$ WSA w Lublinie uwzględnił skargę podatnika i uchylił decyzje zarówno Samorządowego Kolegium Odwoławczego, jak i organu pierwszej instancji. We wniesionej skardze podatnik zarzucił organom błąd w ocenie prawnej, który polegał w szczególności na przyjęciu, że obudowy górnicze podziemnych wyrobisk górniczych stanowią budowle $\mathrm{w}$ postaci tunelu, a umiejscowione w wyrobiskach rurociągi i kolejki podwieszane stanowią budowle w postaci obiektów sieci technicznych. Zdaniem podatnika w konsekwencji spowodowało to błędne opodatkowanie tych obiektów mimo tego, że nie podlegają one opodatkowaniu podatkiem od nieruchomości.

Uwzględniając skargę WSA wytknął oczywiście błędy w postępowaniu dowodowym i nie ma podstaw, aby z tym polemizować. Niezależnie od tego zdecydował się na sformułowanie kilku uwag interesujących z punktu widzenia niniejszego opracowania. Wypada zauważyć, iż WSA oceniając zgodność z prawem stanowiska organów podatkowych w odniesieniu do obudów znajdujących się w przestrzeniach przekopu, pochylni oraz zajezdni lokomotyw, stanął na stanowisku, że użytego w art. 3 pkt 3 Prawa budowlanego pojęcia tunel nie należy ograniczać tylko do drogowych obiektów inżynierskich opisanych pod tą nazwą w ustawie o drogach publicznych. Jak wskazał sąd „skoro z Prawa budowlanego lub z innych przepisów rangi ustawowej nie wynikają $\mathrm{w}$ tym zakresie żadne ograniczenia, to należy uznać za budowlę w rozumieniu wskazanego przepisu każdy obiekt budowlany (niebędący budynkiem lub obiektem małej architektury), który może być określony słowem «tunel» w jego znaczeniu w polskim języku powszechnym. Nie oznacza to jednak, że prawidłowe jest dokonane przez organy podatkowe ustalenie, iż obudowy górnicze, których opodatkowanie jest w sprawie sporne, są tunelami, o jakich mowa w art. 3 pkt 3) Prawa budowlanego, a wobec tego są także budowlami, o których mowa w rozumieniu art. la ust. 1 pkt 2) ustawy o podatkach i opłatach lokalnych. [...] uznanie obudowy górniczej za budowlę podlegającą opodatkowaniu nie może uzasadniać znaczenie słowa «tunel», zgodnie z którym jest to podziemne wyrobisko górnicze mające na obu końcach połączenie z powierzchnią ziemi. Słowo «tunel» określa w tym ujęciu wprost wyrobisko górnicze, a nie budzi wątpliwości, że obudowa górnicza wyrobiskiem nie jest. Ponadto, skoro podziemne wyrobisko

${ }^{82}$ LEX nr 2520156. 
górnicze nie jest przedmiotem opodatkowania podatkiem od nieruchomości ani samo w sobie, ani wespół ze znajdującymi się w nim obiektami, to następstwem uznania za «tunel» w tym znaczeniu obudowy górniczej musiałoby być stwierdzenie, że przedmiotowa obudowa górnicza nie podlega opodatkowaniu". Dodatkowo Sąd podkreślił, iż pojęcie tunel obejmuje nie tylko „odpowiednią obudowę”, ale także przejazd lub przejście, które ona obudowuje jako obiekt stanowiący całość techniczno-użytkową. Skoro zatem w kontekście wyroku TK wyrobisko nie jest przedmiotem opodatkowania, to stosownej ocenie organu podatkowego powinna podlegać nie tylko sama obudowa górnicza (mogąca tworzyć całość techniczno-użytkową z innymi obiektami), ale także ta obudowa w oderwaniu od wyrobiska. Przy takim stanowisku głównym zadaniem staje się nie wydzielenie (a w konsekwencji wyłączenie z opodatkowania) wartości wykonania wyrobiska, ale wyselekcjonowanie tych obiektów, które znajdują się w jego przestrzeni i posiadają cechy budowli w rozumieniu art. 3 pkt 3 (lub pkt 9) Prawa budowlanego. Sąd wyraźnie stwierdził przy tym, że „opierając się na samej analizie językowej nie sposób ustalić, czy obiekt znajdujący się w podziemnym wyrobisku górniczym, w szczególności obudowa górnicza, jest budowlą w rozumieniu art. la ust. 1 pkt 2) ustawy o podatkach i opłatach lokalnych. Ustalenie tej istotnej okoliczności prawnopodatkowego stanu faktycznego wymaga przeprowadzenia postępowania dowodowego z zachowaniem podstawowych zasad postępowania dowodowego, na czele z zasadą prawdy materialnej (art. 122 i art. 187 Ordynacji podatkowej ${ }^{83}$ )".

W wyroku z dnia 17 stycznia 2019 r., II FSK 3270/18, Naczelny Sąd Administracyjny oddalił skargę kasacyjną ${ }^{84}$. Tak samo jak miało to miejsce we wcześniej omówionym wyroku NSA, skarga została oddalona pomimo - jak podkreślił NSA - częściowo błędnego uzasadnienia wyroku WSA. Przede wszystkim NSA uznał, iż $\mathrm{w}$ świetle zebranego materiału dowodowego sąd pierwszej instancji błędnie przyjął, że nie jest możliwe rozważenie zakwalifikowania obudów górniczych jako budowli podlegających opodatkowaniu. Ponadto NSA nie podzielił poglądu WSA, że biegli powinni precyzyjnie opisać (w ujęciu abstrakcyjnym) cechy wzorcowej budowli, a następnie wskazać, $\mathrm{w}$ jakim zakresie obiekty występujące $\mathrm{w}$ danym wyrobisku odpowiadają tym cechom. To organ podatkowy (a nie biegli) dokonuje kwalifikacji w zakresie przedmiotu opodatkowania. Jednocześnie NSA za przedwczesne uznał wywody WSA, w których zakwestionował możliwość uznania obudów górniczych za budowle (tunele). W ocenie NSA stanowisko takie będzie

${ }^{83}$ Ustawa z dnia 29 sierpnia 1997 r. - Ordynacja podatkowa, Dz. U. z 2019 r., poz. 900 z późn. zm. [dalej cyt.: Ordynacja podatkowa].

${ }^{84}$ Sygn. akt II FSK 3270/18. 
można sformułować dopiero przy ponownym rozpoznaniu w ramach rzetelnie przeprowadzonego postępowania dowodowego.

Obserwując najnowszy kierunek orzecznictwa lubelskich sądów administracyjnych, wydaje się, że dochodzi do kolejnej już modyfikacji poglądów. Jest to o tyle pozytywne, że można się w tym doszukiwać pierwszych zwiastunów stabilizacji linii orzeczniczej. Następuje to poprzez zakwalifikowanie obudów wyrobisk górniczych do konstrukcji oporowych ${ }^{85}$. W ten sposób ukształtowała się także praktyka działania biegłych, którzy obudowy łukowe znajdujące się w podziemnych wyrobiskach górniczych traktują jako konstrukcje oporowe (wprost wymienione w art. 3 pkt 3 Prawa budowlanego). Co znamienne, pojęcie „konstrukcji oporowej" nie zostało zdefiniowane w Prawie budowlanym, stąd orzecznictwo sądowe wskazuje, by odkodować je w drodze wykładni językowej oraz systemowej zewnętrznej. Podnosi się, że zwrot „konstrukcja” w języku potocznym oznacza budowlę, strukturę, układ elementów ${ }^{86}$. Do tego przymiotnik „oporowy” oznacza, „stawiający opór" ${ }^{87}$, „nieulegający jakiejś sile" ${ }^{88}$. Oznacza to, że celem konstrukcji oporowej wyrobiska górniczego jest przeciwdziałanie naporowi skał otaczających wnętrze wyrobiska górniczego, co zapewnić ma stateczność górotworu, w którym drążone są wyrobiska górnicze. Uznano, że obudowy górnicze stanowią samodzielne budowle (aby mogły pełnić swoją rolę nie trzeba w nich instalować urządzeń, które stanowiłyby z tą konstrukcją całość techniczno-użytkową).

Odwołując się natomiast do wykładni systemowej zewnętrznej, należy wspomnieć, że pojęcie „konstrukcji oporowej” zostało zdefiniowane w ustawie o drogach publicznych $^{89}$, gdzie wskazano, iż konstrukcja oporowa to budowla przeznaczona do utrzymywania w stanie stateczności nasypu lub wykopu ${ }^{90}$. Dalej wywiedziono, że skoro obudowy górnicze stanowią konstrukcje oporowe, a te wskazane są w przepisach Prawa budowlanego jako budowle, to jako budowle będące w po-

${ }^{85}$ Zob. np. wyrok NSA z dnia 14 grudnia 2018 r., sygn. akt II FSK 86/17, LEX nr 2608601; wyrok NSA z dnia 24 czerwca 2016 r., sygn. akt II FSK 1444/14, LEX nr 2082866; wyrok NSA z dnia 16 lutego 2017 r., sygn. akt II FSK 285/15, LEX nr 2270030; wyrok NSA z dnia 9 marca 2017 r., sygn. akt II FSK 385/15, LEX nr 2273675; wyrok NSA z dnia 9 sierpnia 2018 r., sygn. akt II FSK 2039/16, LEX nr 2533989; wyrok NSA z dnia 9 sierpnia 2018 r., sygn. akt II FSK 2040/16, LEX nr 2534623; wyrok NSA z dnia 14 sierpnia 2018 r., sygn. akt II FSK 2206/16, LEX nr 2558732.

${ }^{86}$ Zob. Stownik Języka Polskiego, red. W. Doroszewski, [w:] https://sjp.pwn.pl/doroszewski/ konstrukcja;5441862.html [dostęp: 4.09.2019].

${ }^{87}$ Zob. Słownik Języka Polskiego, red. W. Doroszewski, [w:] https://sjp.pwn.pl/doroszewski/ oporowy;5466930.html [dostęp: 4.09.2019].

${ }^{88}$ Zob. Stownik Języka Polskiego PWN, [w:] https://sjp.pwn.pl/szukaj/oporowy.html [dostęp: 4.09.2019].

${ }^{89}$ Ustawa z dnia 21 marca 1985 r. o drogach publicznych, Dz. U. z 2018 r., poz. 2068 z późn. zm.

${ }^{90}$ Art. 4 pkt 16 ustawy z dnia 21 marca 1985 r. o drogach publicznych, Dz. U. z 2018 r., poz. 2086 z późn. zm. [dalej cyt.: ustawa o drogach publicznych]. 
siadaniu przedsiębiorcy podlegają opodatkowaniu podatkiem od nieruchomości. W przypadku umiejscowionych w wyrobisku górniczym rurociągów, torowisk, kolei spągowych i tras kolejki podwieszanej, potwierdzono ich kwalifikację jako obiektów liniowych ${ }^{91}$.

Trudno oprzeć się wrażeniu, że WSA w Lublinie w kolejnych trzech wyrokach znacząco zmienił dotychczasową optykę stwierdzając, m.in., że obudowy górnicze są budowlami w rozumieniu przepisów ustawy podatkowej ${ }^{92}$. Tym samym na zasadach określonych $\mathrm{w}$ przepisach podatkowych podlegają opodatkowaniu podatkiem od nieruchomości.

\section{ZAKOŃCZENIE}

Podsumowując przeprowadzoną powyżej analizę dotychczasowej linii orzeczniczej WSA w Lublinie na tle innych orzeczeń wydawanych w kwestiach opodatkowania podziemnych wyrobisk górniczych (włącznie z oceną tych wyroków przez NSA), można pokusić się o kilka zasadniczych wniosków.

Po pierwsze, w sposób stanowczy należy podkreślić doniosłe znaczenie oraz finezję przytoczonych argumentów w wyroku TK. Bez wątpienia wyrok ten w sposób jednoznaczny rozstrzyga mające już swoją wieloletnią historię wątpliwości i kontrowersje dotyczące wyrobiska górniczego w znaczeniu fizycznym i kompleksowym (używając nazewnictwa TK). Także analizowane w niniejszym opracowaniu orzeczenia WSA w sposób bezpośredni powielają przedstawione przez TK wywody. Nie ulega wątpliwości, że taki sposób zapatrywania na tę kwestię utrwali się w praktyce organów podatkowych. Potwierdza to już osobiste doświadczenie autorów niniejszego opracowania.

Po drugie, w ocenie autorów, należy przedstawić zastrzeżenie do części wywodu TK, gdzie stwierdził, iż posłużenie się definicją budowli nie budzi zasadniczo zastrzeżeń w zakresie, w jakim jest ona wykorzystywana na potrzeby prawa budowlanego jako dziedziny prawa administracyjnego. Wydaje się jednak, że także w tym obszarze definicja ta zawiera wady, które stawiają pod znakiem zapytania prawidłowość jej stosowania także w obrębie prawa administracyjnego. Należy wspomnieć, że obok tzw. błędnego koła pośredniego, występują w jej konstrukcji inne nieprawidłowości. Definicja „budowli” formułuje dwa warunki dla obiektów,

\footnotetext{
${ }^{91}$ Art. 3 ust. 3 i ust. 3a Prawa budowlanego.

92 Wyrok WSA w Lublinie z dnia 17 lipca 2019 r., sygn. akt I SA/Lu 105/19, wyrok WSA w Lublinie z dnia 17 lipca 2019 r., sygn. akt I SA/Lu 106/19, wyrok WSA w Lublinie z dnia 17 lipca 2019 r., sygn. akt I SA/Lu 107/19, www.nsa.gov.pl.
} 
które determinują możliwość uznania ich za budowlę. Warunek wystarczający zgodnie z którym budowlami są wszelkie obiekty wskazane enumeratywnie w jej treści oraz warunek konieczny - zgodnie z którym budowlami nie są obiekty zakwalifikowane jako budynki lub obiekty małej architektury. Jakkolwiek w ocenie TK nie budzi zastrzeżeń sformułowanie przez ustawodawcę na potrzeby regulacji prawa budowlanego definicji „budowli” jako definicji otwartej, to w ocenie autorów definiowanie pojęcia „budowli” poprzez pojęcie, którego definicja jest także otwarta, należy ocenić jako wysoce wadliwe. Definicja „obiektu małej architektury”, do której odwołuje się definicja „budowli”, zawiera bowiem otwarty katalog niewielkich obiektów, które mogą być zaliczone do obiektów małej architektury ${ }^{93}$.

Po trzecie, o ile trudno kwestionować słuszność wywodów TK w odniesieniu do tzw. „wyrobiska technicznego”, o tyle analiza powyższych wyroków WSA i NSA wydaje się uzasadniać przypuszczenie, że recepcja argumentacji merytorycznej TK do praktyki orzeczniczej organów podatkowych (a także sądów administracyjnych), nadal nastręcza wiele trudności. Oczywiście słusznie podkreśla się w orzecznictwie sądowym (za TK) konieczność przeprowadzenia rzetelnego postępowania dowodowego zgodnie z obowiązującymi zasadami określonymi dla postępowania podatkowego. Sądy administracyjne mają jednak trudność z rozstrzygnięciem dylematów dotyczących sposobu klasyfikacji obiektów znajdujących się w podziemnym wyrobisku górniczym, co w konsekwencji prowadzi do kazuistyki orzeczniczej - niestety niekiedy ze sobą sprzecznej. Potwierdza to różnorodność wywodów i argumentacji sądów administracyjnych odnoszących się do takich obiektów jak m.in.: tunele, sieci techniczne, konstrukcje oporowe, czy obudowy (te ostatnie nie wymienione przecież expressis verbis w katalogu budowli). Powstają rozbieżności dotyczące tego, czy dane obiekty w wyrobisku górniczym powinny być expressis verbis klasyfikowane jako budowla (w sensie terminologicznym), czy też wystarczy, aby obiekty te posiadały jedynie cechy właściwe dla budowli określone w Prawie budowlanym.

Dodatkowo niepokój budzi zarysowana w orzecznictwie dwoista refleksja. Z jednej strony w niektórych wyrokach sądy stwierdzają, że dla celów opodatkowania nie ma znaczenia szczegółowe ustalanie, czy dany obiekt jest np. tunelem, siecią techniczną, czy konstrukcją oporową. Istotne natomiast jest, żeby organ uznał go za jedną z tych kategorii, bowiem każda $\mathrm{z}$ nich mieści się w legalnej definicji budowli zawartej w Prawie budowlanym. Z drugiej strony, w innych wyrokach, sądy administracyjne nakazywały precyzyjne klasyfikowanie kategorii poszczególnych obiektów, nawet wówczas gdy bezsporne było, że mieszczą się one w legalnym pojęciu budowli. Podkreślano nawet, że nie należy w tym przypadku sugerować

\footnotetext{
${ }^{93}$ Art. 3 pkt 4 Prawa budowlanego.
} 
się nazewnictwem przyjmowanym w odniesieniu do tych obiektów. Obawy występujące na tym tle są tym bardziej uzasadnione, że z objętych analizą wyroków wynika, że nawet powoływani $\mathrm{w}$ tych sprawach biegli mieli poważne trudności z jednoznaczną kwalifikacją występujących w wyrobiskach górniczych obiektów. Powodowało to narastanie komplikacji dla organów podatkowych zobligowanych przecież do rzetelnego i konkretnego określenia przedmiotu opodatkowania.

Po czwarte, słuszny wydaje się pogląd o słabości argumentacji TK, który nie rozstrzyga statusu obiektów innych niż wskazane expressis verbis we wskazanym przepisie. W szczególności nie wyznaczył granicy zaliczenia poszczególnych elementów składających się na przedmiot o wybranej nazwie własnej ${ }^{94}$.

Po piąte, TK wprawdzie trafnie podkreślił konieczność rzetelnego prowadzenia postępowania dowodowego w kontekście klasyfikacji obiektów wyrobisk górniczych jako podlegających opodatkowaniu budowli, to jednak z treści pism procesowych (skarg kasacyjnych) stron postępowania wynika, iż wskazane przez TK w tym względzie dyrektywy interpretacyjne rodzą pokusę wykorzystywania w toku interpretacji nie tylko przepisów odległych od prawa podatkowego (co w węższym zakresie dopuszcza już sama ustawa o podatkach i opłatach lokalnych), ale także niepodatkowych aktów rangi podustawowej. Taki zabieg, jako modyfikujący zakres przedmiotowy opodatkowania, może budzić wątpliwości w świetle przepisu art. 217 Konstytucji.

Po szóste, lektura orzeczeń sądowych oraz rozstrzygnięć organów podatkowych wydaje się nasuwać przypuszczenie, iż pomimo niekwestionowanego istotnego znaczenia i wydźwięku merytorycznego wywodów TK, nadal (po upływie już ośmiu lat) nie udało się wypracować ugruntowanego, jednoznacznego stanowiska w odniesieniu do opodatkowania wyrobisk w sensie technicznym (dostrzegalne są dopiero pierwsze symptomy fragmentarycznej stabilizacji). Niestety analizowane sprawy kończą się ich odesłaniem do ponownego rozpatrzenia przez organy podatkowe bez jednoznacznych wskazówek interpretacyjnych, w odniesieniu do konkretnych obiektów. W ten sposób organy podatkowe stają przed tymi samymi trudnościami, na rozwiązanie których liczyły w toku trwających postępowań sądowych. Tym samym wydaje się, że w praktyce organów podatkowych pojawia się niejednoznaczna sytuacja, jaka miała miejsce przed wydaniem wyroku interpretacyjnego TK. Wpływa to na przewlekłość prowadzonych postępowań, i można przypuszczać, że oddala w czasie ustabilizowanie klarownych zasad opodatkowania wyrobisk górniczych. Wypada uzbroić się w cierpliwość do momentu wykrystalizowania się jednobrzmiącej, z pewnością kazuistycznej, linii orzeczniczej.

94 Tak: J. OzIĘBŁo, Opodatkowanie budowli w świetle wyroku TK z dnia 13 września 2011 r., $P$ 33/09, „Przegląd Podatków Lokalnych i Finansów Samorządowych” 4 (146) 2013, s. 7. 
Niezależnie od powyższego, warto także zwrócić uwagę na swoistą zmienność kierunku założeń w pracach legislacyjnych. Wspomniano już wcześniej, że pojawiła się inicjatywa ustawodawcza na gruncie przepisów ustawy - Prawo górnicze i geologiczne, która w efekcie miała prowadzić do jasnego stanu prawnego w odniesieniu do wyrobisk górniczych (wykluczenia z opodatkowania wyrobisk górniczych w każdym znaczeniu zaproponowanym przez TK - fizycznym, technicznym i kompleksowym). W trakcie procedowania tego projektu wycofano się jednak z tej koncepcji, wykazując niekonsekwencję w rozwiązaniu trwającego przez wiele lat impasu w skutecznym opodatkowaniu wyrobisk górniczych (bądź skutecznym wyłączeniu z opodatkowania).

$\mathrm{W}$ naszej ocenie mając na uwadze wnioski płynące $\mathrm{z}$ dokonanej analizy, uzasadnione wydaje się postawienie tezy o konieczności przeprowadzenia właściwej nowelizacji, która w sposób klarowny, niewieloznaczny, przesądzi wolę ustawodawcy w zakresie opodatkowania (bądź nieopodatkowania) wyrobisk górniczych. Wypada wyrazić przekonanie, że istnieje możliwość ustalenia przy pomocy specjalistów zamkniętego ustawowego katalogu obiektów typowych i niezbędnych dla prawidłowego funkcjonowania wyrobiska górniczego (z punktu widzenia realizowanych tam celów), które ustawodawca uzna w sposób świadomy i niewątpliwy za budowle podlegające opodatkowaniu.

\section{BIBLIOGRAFIA}

\section{ORZECZNICTWO}

Wyrok Trybunału Konstytucyjnego z dnia 3 grudnia 2002 r., sygn. akt P 13/02, LEX nr 57099.

Wyrok Trybunału Konstytucyjnego z dnia 27 listopada 2006 r., sygn. akt K 47/04, OTK ZU nr 10/A/2006, poz. 153.

Wyrok Trybunału Konstytucyjnego z dnia 2 kwietnia 2007 r., sygn. akt SK 19/06, OTK ZU nr 4/A/2007, poz. 37.

Wyrok Trybunału Konstytucyjnego z dnia 9 października 2007 r., sygn. akt SK 70/06; z 27 listopada 2007 r., sygn. SK 39/06, OTK ZU nr 10/A/2007, poz. 127.

Wyrok Trybunału Konstytucyjnego z dnia 10 września 2010 r., sygn. akt P 44/09, OTK ZU nr 7/A/2010, poz. 68.

Postanowienie Trybunału Konstytucyjnego z dnia 27 kwietnia 2004 r., sygn. akt P 16/03, LEX nr 107520.

Postanowienie Trybunału Konstytucyjnego z dnia 8 kwietnia 2008 r., sygn. akt SK 80/06, OTK ZU nr 3/A/2008, poz. 51.

Postanowienie Trybunału Konstytucyjnego z dnia 6 kwietnia 2011 r., sygn. akt SK 21/07, OTK ZU nr 3/A/2011, poz. 28

Uchwała Sądu Najwyższego z dnia 12 marca 2002 r., sygn. akt III ZP 34/01, OSNP 2002, nr 23, poz. 561. 
Wyrok Sądu Najwyższego z dnia 22 października 1992 r., sygn. akt III ARN 50/92, LEX nr 23007. Uchwała Naczelnego Sądu Administracyjnego z dnia 18 grudnia 1997 r., sygn. akt FPK 24/97, ONSA nr 2/1998, poz. 46.

Uchwała Naczelnego Sądu Administracyjnego z dnia 29 listopada 1999 r., sygn. akt FPK 3/99, ONSA 2000, nr 2, poz. 59.

Uchwała 7 sędziów Naczelnego Sądu Administracyjnego z dnia 2 lipca 2001 r., sygn. akt FPS 2/01, LEX nr 48076.

Uchwała Naczelnego Sądu Administracyjnego z dnia 27 kwietnia 2009 r., sygn. akt II FPS 1/09, LEX nr 489351.

Wyrok Naczelnego Sądu Administracyjnego z dnia 6 listopada 1996 r., sygn. akt SA/Ka 1913/95, ONSA 1997, nr 4, poz. 159.

Wyrok Naczelnego Sądu Administracyjnego z dnia 21 marca 2003 r., sygn. akt I SA/Po 315/02, LEX nr 144616.

Wyrok Naczelnego Sądu Administracyjnego z dnia 3 lutego 2006 r., sygn. akt II FSK 656/05, LEX nr 193322.

Wyrok Naczelnego Sądu Administracyjnego z dnia 20 września 2007 r., sygn. akt II FSK 1016/06, LEX nr 389400.

Wyrok Naczelnego Sądu Administracyjnego z dnia 27 listopada 2007 r., sygn. akt II FSK 1329/06, LEX nr 926689.

Wyrok Naczelnego Sądu Administracyjnego z dnia 11 czerwca 2008 r., sygn. akt II FSK 508/07, LEX nr 470141.

Wyrok Naczelnego Sądu Administracyjnego z dnia 29 stycznia 2009 r., sygn. akt II FSK 1407/07, LEX nr 537592.

Wyrok Naczelnego Sądu Administracyjnego z dnia 30 czerwca 2009 r., sygn. akt II FSK 1411/07, LEX nr 513323.

Wyrok Naczelnego Sądu Administracyjnego z dnia 7 października 2009 r., sygn. akt II FSK 635/08, LEX nr 532352.

Wyrok Naczelnego Sądu Administracyjnego z dnia 5 stycznia 2010 r., sygn. akt II FSK 1101/08, LEX nr 553973.

Wyrok Naczelnego Sądu Administracyjnego z dnia 15 stycznia 2010 r., sygn. akt II FSK 1114/09, LEX nr 558865.

Wyrok Naczelnego Sądu Administracyjnego z dnia 20 kwietnia 2010 r., sygn. akt II FSK 2112/08, LEX nr 576210.

Wyrok Naczelnego Sądu Administracyjnego z dnia 13 maja 2010 r., sygn. akt II FSK 2168/08, LEX nr 596292.

Wyrok Naczelnego Sądu Administracyjnego z dnia 13 maja 2010 r., sygn. akt II FSK 1066/09, LEX nr 595691

Wyrok Naczelnego Sądu Administracyjnego z dnia 13 maja 2010 r., sygn. akt II FSK 1931/09, LEX nr 596091.

Wyrok Naczelnego Sądu Administracyjnego z dnia 13 maja 2010 r., sygn. akt II FSK 1932/09, LEX nr 596093.

Wyrok Naczelnego Sądu Administracyjnego z dnia 20 maja 2010 r., sygn. akt II FSK 63/09, LEX nr 596546.

Wyrok Naczelnego Sądu Administracyjnego z dnia 27 maja 2010 r., sygn. akt II FSK 2049/09, LEX nr 590575. 
Wyrok Naczelnego Sądu Administracyjnego z dnia 13 sierpnia 2010 r., sygn. akt II FSK 2069/09, LEX nr 745719.

Wyrok Naczelnego Sądu Administracyjnego z dnia 13 sierpnia 2010 r., sygn. akt II FSK 342/09, LEX nr 590685.

Wyrok Naczelnego Sądu Administracyjnego z dnia 19 października 2010 r., sygn. akt II FSK 907/09, LEX nr 786261.

Wyrok Naczelnego Sądu Administracyjnego z dnia 13 kwietnia 2011 r., sygn. akt II FSK 144/10, LEX nr 787326.

Wyrok Naczelnego Sądu Administracyjnego z dnia 13 kwietnia 2011 r., sygn. akt II FSK 1310/10, LEX nr 1081250.

Wyrok Naczelnego Sądu Administracyjnego z dnia 24 czerwca 2016 r., sygn. akt II FSK 1444/14, LEX nr 2082866.

Wyrok Naczelnego Sądu Administracyjnego z dnia 16 lutego 2017 r., sygn. akt II FSK 285/15, LEX nr 2270030.

Wyrok Naczelnego Sądu Administracyjnego z dnia 9 marca 2017 r., sygn. akt II FSK 385/15, LEX nr 2273675.

Wyrok Naczelnego Sądu Administracyjnego z dnia 9 sierpnia 2018 r., sygn. akt II FSK 2039/16, LEX nr 2533989.

Wyrok Naczelnego Sądu Administracyjnego z dnia 9 sierpnia 2018 r., sygn. akt II FSK 2040/16, LEX nr 2534623.

Wyrok Naczelnego Sądu Administracyjnego z dnia 14 sierpnia 2018 r., sygn. akt II FSK 2206/16, LEX nr 2558732.

Wyrok Naczelnego Sądu Administracyjnego z dnia 14 grudnia 2018 r., sygn. akt II FSK 86/17, LEX nr 2608601.

Wyrok Wojewódzkiego Sądu Administracyjnego we Wrocławiu z dnia 11 września 2004 r., sygn. akt I SA/Wr 3364/02, niepubl.

Wyrok Wojewódzkiego Sądu Administracyjnego we Wrocławiu z dnia 9 listopada 2004 r., sygn. akt I SA/Wr 3364/03, LEX nr 715795.

Wyrok Wojewódzkiego Sądu Administracyjnego we Wrocławiu z dnia 5 października 2006 r., sygn. akt I SA/Wr 161/05, LEX nr 894208.

Wyrok Wojewódzkiego Sądu Administracyjnego we Wrocławiu z dnia 15 marca 2007 r., sygn. akt I SA/Wr 1811/06, LEX nr 923639.

Wyrok Wojewódzkiego Sądu Administracyjnego we Wrocławiu z dnia 15 marca 2007 r., sygn. akt I SA/Wr 1814/06, LEX nr 305425.

Wyrok Wojewódzkiego Sądu Administracyjnego we Wrocławiu z dnia 16 maja 2007 r., sygn. akt I SA/Wr 1596/06, LEX nr 295449.

Wyrok W Wojewódzkiego Sądu Administracyjnego we Wrocławiu z dnia 26 września 2007 r., sygn. akt I SA/Wr 964/07, LEX nr 1009632.

Wyrok Wojewódzkiego Sądu Administracyjnego w Gdańsku z dnia 28 listopada 2007 r., sygn. akt I SA/Gd 598/07, LEX nr 326607.

Wyrok Wojewódzkiego Sądu Administracyjnego we Wrocławiu z dnia 18 grudnia 2007 r., sygn. akt I SA/Wr 1006/07, LEX nr 1007765.

Wyrok Wojewódzkiego Sądu Administracyjnego we Wrocławiu z dnia 18 grudnia 2007 r., sygn. akt I SA/Wr 1004/07, LEX nr 1007763.

Wyrok Wojewódzkiego Sądu Administracyjnego we Wrocławiu z dnia 6 lutego 2008 r., sygn. akt I SA/Wr 944/07, LEX nr 471151. 
Wyrok Wojewódzkiego Sądu Administracyjnego we Wrocławiu z dnia 14 kwietnia 2008 r., sygn. akt I SA/Wr 1572/07, LEX nr 380935.

Wyrok Wojewódzkiego Sądu Administracyjnego w Gliwicach z dnia 9 lutego 2009 r., sygn. akt I SA/Gl 345/08, LEX nr 511372.

Wyrok Wojewódzkiego Sądu Administracyjnego w Gliwicach z dnia 16 lutego 2009 r., sygn. akt I SA/G1 953/08, LEX nr 512078.

Wyrok Wojewódzkiego Sądu Administracyjnego w Lublinie z dnia 2 lipca 2010 r., sygn. akt I SA/ Lu 502/09, LEX nr 603339.

Wyrok Wojewódzkiego Sądu Administracyjnego w Lublinie z dnia 22 września 2010 r., sygn. akt I SA/Lu 657/09, LEX nr 749489.

Wyrok Wojewódzkiego Sądu Administracyjnego we Wrocławiu z dnia 5 stycznia 2011 r., sygn. akt sygn. akt III SA/Wr 579/10, LEX nr 953895.

Wyrok Wojewódzkiego Sądu Administracyjnego w Gliwicach z dnia 19 czerwca 2012 r., sygn. akt I SA/G1 893/11, LEX nr 1219602.

Wyrok Wojewódzkiego Sądu Administracyjnego w Lublinie z dnia 17 lipca 2019 r., sygn. akt I SA/ Lu 105/19, niepubl.

Wyrok Wojewódzkiego Sądu Administracyjnego w Lublinie z dnia 17 lipca 2019 r., sygn. akt I SA/ Lu 106/19, niepubl.

Wyrok Wojewódzkiego Sądu Administracyjnego w Lublinie z dnia 17 lipca 2019 r., sygn. akt I SA/ Lu 107/19, niepubl.

Postanowienie Wojewódzkiego Sądu Administracyjnego w Gliwicach z dnia 1 czerwca 2009 r., sygn. akt I SA/G1 110/09, LEX nr 532941.

\section{LITERATURA}

BANASIK Paweł: Załącznik do ustawy - prawo budowlane a jego wpływ na określenie przedmiotu, w podatku od nieruchomości, Przegląd Podatków Lokalnych i Finansów Samorządowych 3 (205) 2018, s. 6-12.

BrZeziŃSKi Bogumił, Morawski Wojciech: Glosa do wyroku Trybunału Konstytucyjnego z dnia 13 września 2011 r. (P 33/09) - opodatkowanie podatkiem od nieruchomości podziemnych wyrobisk górniczych, Przeglad Orzecznictwa Podatkowego 1 (2012), s. 22-28.

BrzeziŃski Bogumił, NitA Adam: Glosa do wyroku Trybunału Konstytucyjnego z dnia 13 września 2011 r., P 33/09 - pojęcie budowli w podatku od nieruchomości, Przegląd Orzecznictwa Podatkowego 1 (2013), s. 7-11.

BrZeZińsKi Bogumił, KALINOwsKi Marek: Glosa do wyroku NSA z dnia 6 listopada 1996 r., SA/ Ka 1913/95, Przeglad Orzecznictwa Podatkowego 1 (1999), s. 96-98.

Dowgier Rafał: Projektowane zmiany w ustawie o podatkach i opłatach lokalnych, Przeglad Podatków Lokalnych i Finansów Samorządowych 2 (156) 2014, s. 6-11.

Dowgier Rafał: Budynek czy budowla? Kilka uwag na tle wyroku TK z dnia 13 grudnia 2017 r., SK 48/15, Przegląd Podatków Lokalnych i Finansów Samorządowych 4 (206) 2018, s. 33-40.

FlorczaK-Wątor Monika: Orzeczenia Trybunału Konstytucyjnego i ich skutki prawne, Poznań: Ars Boni et Aequi 2006.

GIL Krzysztof: Glosa do wyroku WSA w Gliwicach z dnia 9 lutego 2009 r., I SA/Gl 345/08 opodatkowanie podatkiem od nieruchomości podziemnych wyrobisk górniczych, Przegląd Orzecznictwa Podatkowego 6 (2009), s. 532-536. 
Granat Mirosław: Prawo konstytucyjne w pytaniach i odpowiedziach, Warszawa: Wolters Kluwer 2014.

HANusz Antoni: Obowiązek podatkowy w podatku od nieruchomości a wyrobisko górnicze, Glosa 2 (2001), s. 20-29.

JukIEl Grzegorz, WĄSIEWSKI Grzegorz J., SAPIEŻKo-SAMORDAK Joanna: Opodatkowanie wyrobisk górniczych. Uwagi na tle pytania prawnego skierowanego do Trybunału Konstytucyjnego, Monitor Podatkowy 1 (2010), s. 24-29.

KARCZYŃSKi Łukasz: Glosa do wyroku NSA z dnia 10 marca 2010 r., II FSK 1765/08 - istnienie budynku lub budowli w rozumieniu art. 6 ust. 2 ustawy o podatkach i opłatach lokalnych, Przeglad Orzecznictwa Podatkowego 5 (2011), s. 433-436.

Krок Wojciech: Budowla w podatku od nieruchomości, Warszawa 2010, LEX/el.

Mastalski Ryszard: Opodatkowanie budowli w wyrobiskach górniczych, Przegląd Podatkowy 12 (2001), s. 37-39.

Mastalski Ryszard, Glosa do wyroku TK z 13 września 2011 r., P 33/09, Przegląd Sejmowy 2 (109) 2012, s. 177-182.

MorawsKi Wojciech, Banasik Paweł: Wyrok TK z dnia 13 września 2011 r., P 33/09 a orzecznictwo sądów administracyjnych, Monitor Podatkowy 1 (2014), s. 11-19.

Olechno Artur: Wpływ orzecznictwa TK na stosowanie prawa podatkowego w Polsce, Przeglad Podatków Lokalnych i Finansów Samorządowych 9 (151) 2013, s. 32-35.

Ozį̨Bєo Janusz: Opodatkowanie budowli w świetle wyroku TK z dnia 13 września 2011 r., P 33/09, Przegląd Podatków Lokalnych i Finansów Samorządowych 4 (146) 2013, s. 6-10.

PAHL Bogumił: Glosa do wyroku NSA z dnia 13 września 2012 r., II FSK 1048/12, LEX/el. 2013.

PoPŁAwski Mariusz: Nowa definicja obiektu budowlanego w prawie budowlanym a opodatkowanie budowli podatkiem od nieruchomości, Przegląd Podatków Lokalnych i Finansów Samorządowych 7 (185) 2016, s. 6-10.

RADZIKOwSKI Krzysztof: Opodatkowanie podatkiem od nieruchomości podziemnych wyrobisk górniczych po wyroku Trybunału Konstytucyjnego z 13 września 2011 r., P 33/09, Finanse Komunalne 3 (2013), s. 66-75.

Rogowski Łukasz: Opodatkowanie urządzeń budowlanych podatkiem od nieruchomości, Przegląd Podatków Lokalnych i Finansów Samorządowych 2 (216) 2019, s. 16-20.

Słownik Języka Polskiego, red. W. Doroszewski, [w:] https://sjp.pwn.pl/doroszewski/budowla;5415191. html [dostęp: 4.09.2019].

Słownik Języka Polskiego, red. W. Doroszewski, [w:] https://sjp.pwn.pl/doroszewski/konstrukcja;5441862.html [dostęp: 4.09.2019].

Słownik Języka Polskiego, red. W. Doroszewski, [w:] https://sjp.pwn.pl/doroszewski/oporowy;5466930. html [dostęp: 4.09.2019].

Słownik Języka Polskiego PWN, [w:] https://sjp.pwn.pl/szukaj/oporowy.html [dostęp: 4.09.2019]. TrzciŃski Janusz: Orzeczenia interpretacyjne Trybunału Konstytucyjnego, Państwo i Prawo 1 (2002). Woś Tomasz: Wyroki interpretacyjne i zakresowe w orzecznictwie Trybunału Konstytucyjnego, Studia Iuridica Lublinensia 3 (25) 2016, s. 985-995.

WronkowsKa Sławomira, ZiEmBiński Zygmunt: Zarys teorii prawa, Poznań: Ars Boni et Aequi 2001. ZIEMBiŃSKi Zygmunt: Problemy podstawowe prawoznawstwa, Warszawa: PWN 1980. 


\section{PRAKTYKA OPODATKOWANIA WYROBISK GÓRNICZYCH PO WYROKU TRYBUNAŁU KONSTYTUCYJNEGO Z DNIA 13 WRZEŚNIA 2011 ROKU (P 33/09)}

\section{Streszczenie}

Od dłuższego czasu, kwestią rodzącą liczne rozbieżności w orzecznictwie organów podatkowych i sądów administracyjnych jest zagadnienie opodatkowania podatkiem od nieruchomości podziemnych wyrobisk górniczych i znajdujących się w nich urządzeń. Wątpliwości wynikają przede wszystkim z niejasności definicji legalnych dotyczących wspomnianej problematyki. Stan taki w sposób bezpośredni wpływał na chwiejność rozstrzygnięć organów podatkowych i sądów administracyjnych.

Wobec stale narastających wątpliwości Wojewódzki Sąd Administracyjny w Gliwicach wystąpił do Trybunału Konstytucyjnego z wnioskiem o zbadanie konstytucyjności przepisów ustawy o podatkach i opłatach lokalnych w zakresie, w jakim definiują budowlę jako przedmiot opodatkowania. Trybunał Konstytucyjny wydał wyrok interpretacyjny, który ma przełomowe znaczenie dla praktyki opodatkowania wyrobisk górniczych. Przede wszystkim rozstrzygnął zasadniczy dylemat dotyczący wyrobiska górniczego zarówno w znaczeniu fizycznym, jak i kompleksowym, przesądzając, iż jako takie nie stanowi przedmiotu opodatkowania. Trybunał Konstytucyjny stwierdził, że podziemne wyrobiska górnicze nie są bowiem obiektami budowlanymi (urządzeniami budowlanymi) w ujęciu Prawa budowlanego, lecz przestrzenią powstałą w wyniku prac górniczych, a w konsekwencji nie mogą być kwalifikowane jako budowle na gruncie przepisów Prawa budowlanego. Tym samym nie stanowią one przedmiotu opodatkowania podatkiem od nieruchomości ani samodzielnie (jako wyrobiska w znaczeniu fizycznym), ani razem ze znajdującą się w nich infrastrukturą (jako wyrobiska w znaczeniu kompleksowym). Odmiennie natomiast jest w przypadku infrastruktury usytuowanej w podziemnych wyrobiskach górniczych. Poszczególne jej elementy mogą być zakwalifikowane jako obiekty budowlane (urządzenia budowlane) w ujęciu Prawa budowlanego, a tym samym jako budowle na gruncie ustawy o podatkach i opłatach lokalnych.

$\mathrm{O}$ ile kwestia wyłączenia $\mathrm{z}$ opodatkowania podziemnych wyrobisk górniczych (w znaczeniu fizycznym i kompleksowym) nie budzi już kontrowersji w orzecznictwie sądowym, o tyle opodatkowanie „wyrobiska w sensie technicznym" nadal - pomimo upływu kilku lat od wyroku TK z 2011 r. - prowokuje liczne trudności. Wskazuje na to analiza najnowszych orzeczeń sądowych odnoszących się do tego samego podmiotu w zakresie sporu trwającego od dłuższego już czasu - w swej genezie sięgającej okresu na długo sprzed daty wydania wspomnianego wyroku TK.

W opracowaniu dokonano wnikliwej analizy najnowszych orzeczeń sądów administracyjnych przez pryzmat tezy i argumentacji zawartej w wyroku TK. Zaprezentowano szereg wniosków szczegółowych. Autorzy przyjęli też tezę główną, iż uzasadniona wydaje się konieczność przeprowadzenia właściwej nowelizacji, która w sposób klarowny, niewieloznaczny, przesądzi wolę ustawodawcy w zakresie opodatkowania (bądź nieopodatkowania) wyrobisk górniczych. Wyrażono przy tym przekonanie, że istnieje możliwość ustalenia przy pomocy specjalistów zamkniętego ustawowego katalogu obiektów typowych i niezbędnych dla prawidłowego funkcjonowania wyrobiska górniczego (z punktu widzenia realizowanych tam celów), które ustawodawca uzna w sposób świadomy i niewątpliwy za budowle podlegające opodatkowaniu.

Słowa kluczowe: wyrobisko górnicze; obiekty budowlane; budowla; podatek od nieruchomości 


\section{THE PRACTICE OF THE TAXATION OF POST-MINING PITS AFTER THE JUDGEMENT OF THE CONSTITUTIONAL COURT OF 13 SEPTEMBER 2011 (P 33/09)}

\section{Sum mary}

For a long time, the issue of the taxation of underground post-mining pits and their equipment with the real estate tax has been an issue that has given rise to divergent judicial decisions of tax authorities and administrative courts. Doubts arise, first and foremost, from the ambiguity of legal definitions concerning the issues mentioned above. Such a situation led directly to certain divergence among different decisions of tax authorities and administrative courts.

As a result of constantly growing doubts, the Voivodship Administrative Court in Gliwice submitted a motion to the Constitutional Tribunal to examine the constitutionality of the provisions of the Local Taxes and Fees Act to the extent to which they define a building as a subject of taxation. The Constitutional Tribunal issued an interpretative judgement which is of crucial importance for the practice of the taxation of post-mining pits. First and foremost, it resolved the fundamental dilemma concerning the post-mining pit both in its physical and comprehensive sense, deciding that as such a post mining pit does not constitute the subject of taxation.

The Constitutional Tribunal stated that underground post-mining pits are not construction features (services and facilities) in terms of the Construction Law, but space created as a result of mining works, and consequently the cannot be qualified as structures under the provisions of the Construction Law. Therefore, they are not subject to real estate tax either independently (as excavations in the physical sense) or together with their infrastructure (as excavations in the comprehensive sense). The situation is different in the case of infrastructure located in underground post-mining pits. Its individual elements may be classified as construction structures (construction equipment) under the Construction Law, and thus as structures under the Local Taxes and Fees Act.

While the issue of exclusion of underground post mining pits from taxation (in both physical and comprehensive sense) is no longer a controversial issue in judicial decisions, the taxation of "post-mining pits in the technical sense" continues - despite the fact that several years have passed since the judgment of the Constitutional Tribunal in 2011, and this situation provokes numerous difficulties. This is reflected by the analysis of the most recent judicial decisions relating to the same entity with respect to a dispute that has been going on for a long time - in its genesis reaching back to the period long before the day in which the aforementioned judgment of the Constitutional Tribunal was issued.

The article thoroughly analyses the latest judicial decisions of administrative courts through the prism of the premise and arguments contained in the judgment of the Constitutional Tribunal. A number of detailed conclusions were presented. The authors also adopted the main premise that the necessity to carry out a proper amendment seems justified. Such an amendment would in a clear, unambiguous manner determine the legislator's will in the area of the taxation (or non-taxation) of post-mining pits. A view was also expressed that it was possible to establish, with the help of specialists, a closed statutory catalogue of objects that would be typical and necessary for the proper functioning of post-mining pits (from the point of view of the objectives pursued there), which the legislator would consciously and undoubtedly consider to be taxable structures.

Key words: post-mining pits; construction features; services and facilities; property tax 